\title{
Hydrogeochemistry and water-rock interactions in the urban area of Puebla Valley aquifer (Mexico)
}

\author{
Edith R. Salcedo Sánchez ${ }^{\mathrm{a}, *}$, Sofía E. Garrido Hoyos ${ }^{\mathrm{b}}$, Ma. Vicenta Esteller ${ }^{\mathrm{c}}$, \\ Manuel Martínez Morales ${ }^{\mathrm{b}}$, Ariadna Ocampo Astudillo ${ }^{\mathrm{b}}$ \\ ${ }^{a}$ Universidad Nacional Autónoma de México, Facultad de Ingeniería, Posgrado en Ingeniería Ambiental, Paseo Cuauhnahuac 8532, Progreso, 62550 Jiutepec, Morelos, \\ Mexico \\ b Instituto Mexicano de Tecnología del Agua (IMTA), Paseo Cuauhnahuac 8532, Progreso, 62550 Jiutepec, Morelos, Mexico \\ c Centro Interamericano de Recursos del Agua (CIRA), Facultad de Ingeniería, Universidad Autónoma del Estado de México, Cerro de Coatepec, Ciudad Universitaria, \\ 50130 Toluca, Estado de México, Mexico
}

\section{A R T I C L E I N F O}

\section{Keywords:}

Groundwater

Water-rock interactions

Saturation index

Dedolomitization process

Heavy metals

\begin{abstract}
A B S T R A C T
The urban area of Puebla Valley aquifer is seated in Puebla City and neighbor municipalities. Puebla is the fourth largest city in Mexico, where there are significant industrial zones and a large population. Water needs are almost exclusively met by groundwater, which has brought intense exploitation of groundwater resources and water quality degradation. The present study investigates the hydrogeochemical changes in groundwater, particularly focuses on the chemical changes produced by upwelling mineralized water. These concentrations may represent potential risks to the health of the population.

The groundwater presented five types of families $\mathrm{Ca}-\mathrm{HCO}_{3}, \mathrm{Mg}-\mathrm{HCO}_{3}, \mathrm{Mix}-\mathrm{HCO}_{3}, \mathrm{HCO}_{3}-\mathrm{Ca}-\mathrm{SO}_{4}$ and Ca-SO $\mathrm{S}_{4}$ The high concentrations of sulphates, calcium and magnesium are reflected in high TDS and Total Hardness. The samples collected showed detectable concentrations of $\mathrm{F}^{-}$, Fe, Mn, Ba, Sr, Cu, Zn, B and Li. The limitations for its use as drinking water are given by the high values of TDS, sulphates, total hardness and Mn.

Geochemical modeling using Geochemist's Workbench (GWB) and PHREEQC software enabled the computation of the saturation index of mineral phases with ions in solution and speciation ions. Groundwater was initially in equilibrium with calcite; however, due to the changes in hydrogeological conditions, gypsum and dolomite are being dissolved until new equilibrium conditions are met. The additional calcium and carbonate in the water causes calcite to become oversaturated and to precipitate. Evidence of dedolomitization reactions and common ion effect is illustrated by concurrent increases in calcium and magnesium concentrations in the groundwater.
\end{abstract}

\section{Introduction}

The sustainability of freshwater resources is undoubtedly the most critical issue in the urban zones, as evidenced by the increasing water stress worldwide. As a result, groundwater is one of the main players in the social and economic growth in Mexico. The role in sustainable development of water requires understanding their origin and renewability (Morán-Ramírez et al., 2016). These problems are particularly evident in the policy objectives and management that require comprehensive assessments of potential groundwater resources, groundwater chemical composition and anthropogenic and geogenic sources of pollution (Edmunds et al., 2002).

In Mexico, the groundwater is an important source of supply; it is mainly used for irrigation, population and industrial facilities (INEGI, 2010). Groundwater sources are the most important means of fulfilling the water needs of the country, representing $>70 \%$ of the water supply for industry, and providing a water source for $>70 \%$ of the 110 million inhabitants (CONAGUA, 2015; Esteller et al., 2012; Carrillo-Rivera et al., 2008).

Groundwater quality is a key factor for determining the use of water purposes (Esteller et al., 2012; Nandimandalam, 2012; Edmunds et al., 2002). In Mexico, the aquifers are actually at risk due to the population growth, industrialization, urbanization and changing land use patterns (Martin del Campo et al., 2014; Carrillo-Rivera et al., 2008). The assessment of processes that control groundwater chemical composition is essential for effective water management and protection of the water

\footnotetext{
* Corresponding author at: CATEDRAS CONACYT-Facultad de Ciencias de la Tierra Universidad Autónoma de Guerrero, Ex Hacienda de San Juan Bautista s/n, Taxco el Viejo, 40323 Taxco de Alarcón, Guerrero, Mexico.

E-mail address: ersalcedo@conacyt.mx (E.R. Salcedo Sánchez).
} 


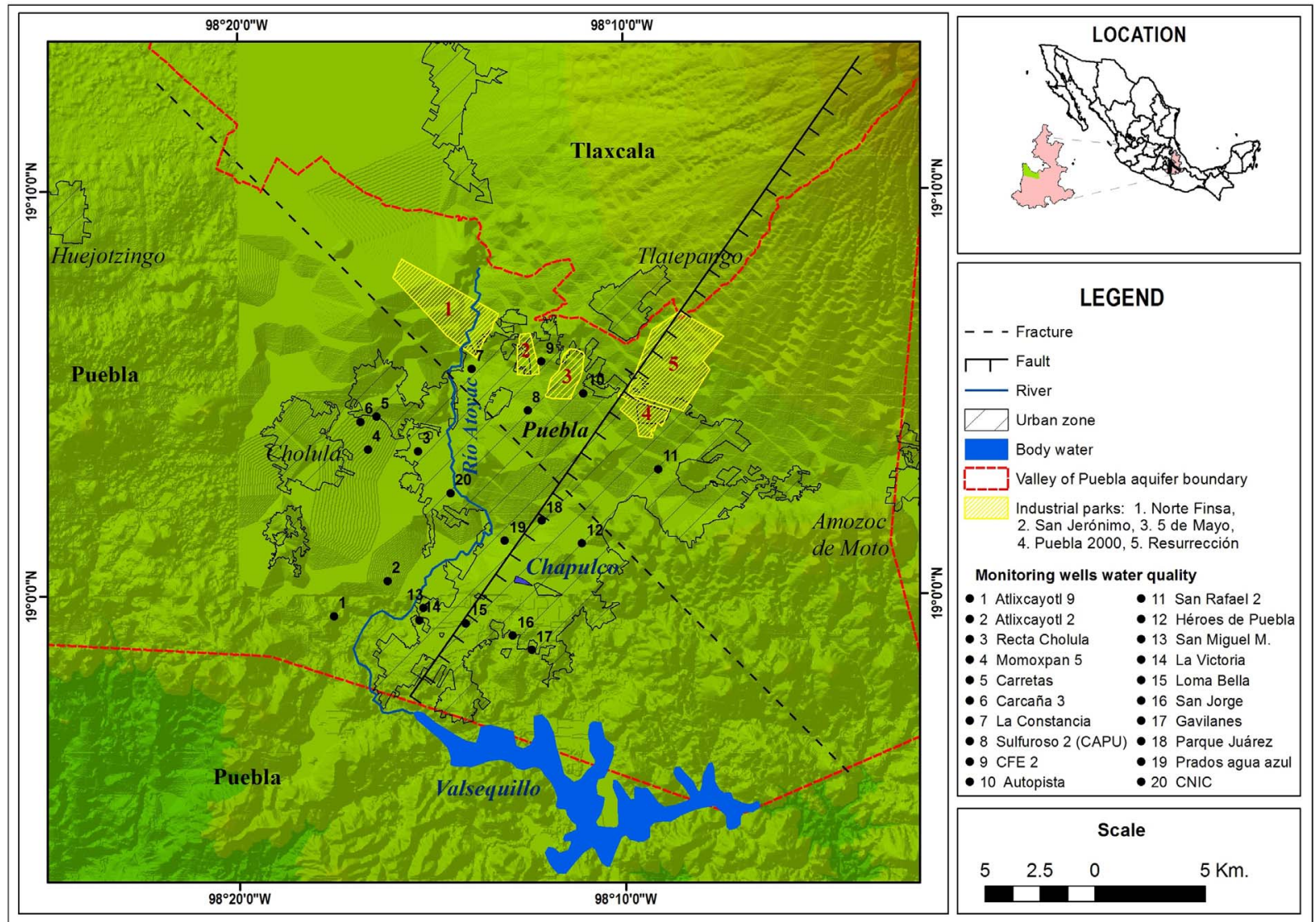

Fig. 1. Location of the study area and sampled wells.

resources. For example, modification can occur via natural processes, such as water-rock interactions (e.g. mineral dissolution), which vary with hydrogeological conditions or via anthropogenic activities as agriculture, industry, and urban development (Morán-Ramírez et al., 2016; Nandimandalam, 2012; Jalali, 2006).

Groundwater chemical composition provides valuable information to determine the origin, transit time, flow patterns and regimes of water, geological structure and mineralogy of the aquifers, and hydrogeochemical processes (Morán-Ramírez et al., 2016; Jalali and Jalali, 2016). The chemical composition of groundwater refers the interaction between the aqueous solution and rock, and reflects alterations induced by dissolution of thermodynamic unstable mineral and formation of new stable minerals (Morán-Ramírez et al., 2016; Carucci et al., 2012; Jalali and Jalali, 2016).

Groundwater is the most important source for water supply in Puebla city, intense urban and industrial development have placed high demand of groundwater resources and also these resources are at greater risk to degradation of quality. Furthermore, this development of the area make groundwater a critical resource for human activities (Salcedo-Sánchez et al., 2016; Gárfias et al., 2010; Flores-Márquez et al., 2006). According to Flores-Márquez et al. (2006) and Gárfias et al. (2010), the most significant effect is the degradation in the quality of freshwater in the upper aquifer due to mixing with sulphydric water which rises from the deep aquifer. This mineralized water contains concentrations of sulphates and sulphurs above the WHO's quality standards for drinking water (250 and $0.05 \mathrm{mg} \mathrm{L}^{-1}$, respectively).

The aim of this study was to define the principal hydrogeochemical process controlling groundwater quality (major and minor ions, and heavy metals), with the particular scope on the chemical changes produced by water-rock interactions and upwelling of mineralized water in the urban zone of the Puebla Valley aquifer.

\section{Study area}

Puebla Valley aquifer is located in the central region of the Mexican Republic, at the center of the State of Puebla at 2160 masl (meters above sea level) and an extension of about $2151 \mathrm{~km}^{2}$. The study area is located between the parallels $18^{\circ} 54^{\prime}$ and $19^{\circ} 30^{\prime}$ and the meridians $98^{\circ} 00^{\prime}$ and $98^{\circ} 40^{\prime}$ west of Greenwich (Fig. 1). The main rivers running through the Puebla Valley aquifer are the Atoyac, Zahuapan and Alseseca (Salcedo-Sánchez et al., 2013; Gárfias et al., 2010). The study area includes the Puebla City and neighboring municipalities (Fig. 1).

The climate is mild and the precipitation is moderate during summer. The annual mean temperature is $16.6^{\circ} \mathrm{C}$, with a maximum of $21.3^{\circ} \mathrm{C}$ in May and a minimum of $10.8^{\circ} \mathrm{C}$ in February. Annual mean precipitation in the basin ranges from 650 to $900 \mathrm{~mm}$, with maximums of $1000 \mathrm{~mm}$ in volcanic zones in the eastern and western portions of the basin (Gárfias et al., 2010).

The study area focus on the urban zone, vegetation cover and land use has changed in the Puebla Valley aquifer area over the time, currently the urban area of Puebla city represents $70 \%$ of the metropolitan area (Fig. 2), this percentage will increase like the last 20 years due the urbanization and industrialization phenomena in the area (INEGI, 2010; Salcedo-Sánchez et al., 2016). This situation was intensified by the establishment of an industrial zone at north of the city and the construction of infrastructure like roads, producing the urban expansion towards the west. The declaration of the vegetation cover and land use for Angelópolis in 1993, worsened the situation, consolidating a new node of services between Puebla, San Pedro Cholula and San Andres Cholula (Ayuntamiento de Puebla, 2014).

In the urban area currently, there are five industrial parks (Fig. 1): "Norte FINSA", "5 Mayo", "San Jerónimo", "Resurrección" and "Puebla 2000" (Ayuntamiento de Puebla, 2014). This growth in both population and productive activities has created a high demand for water, which is 


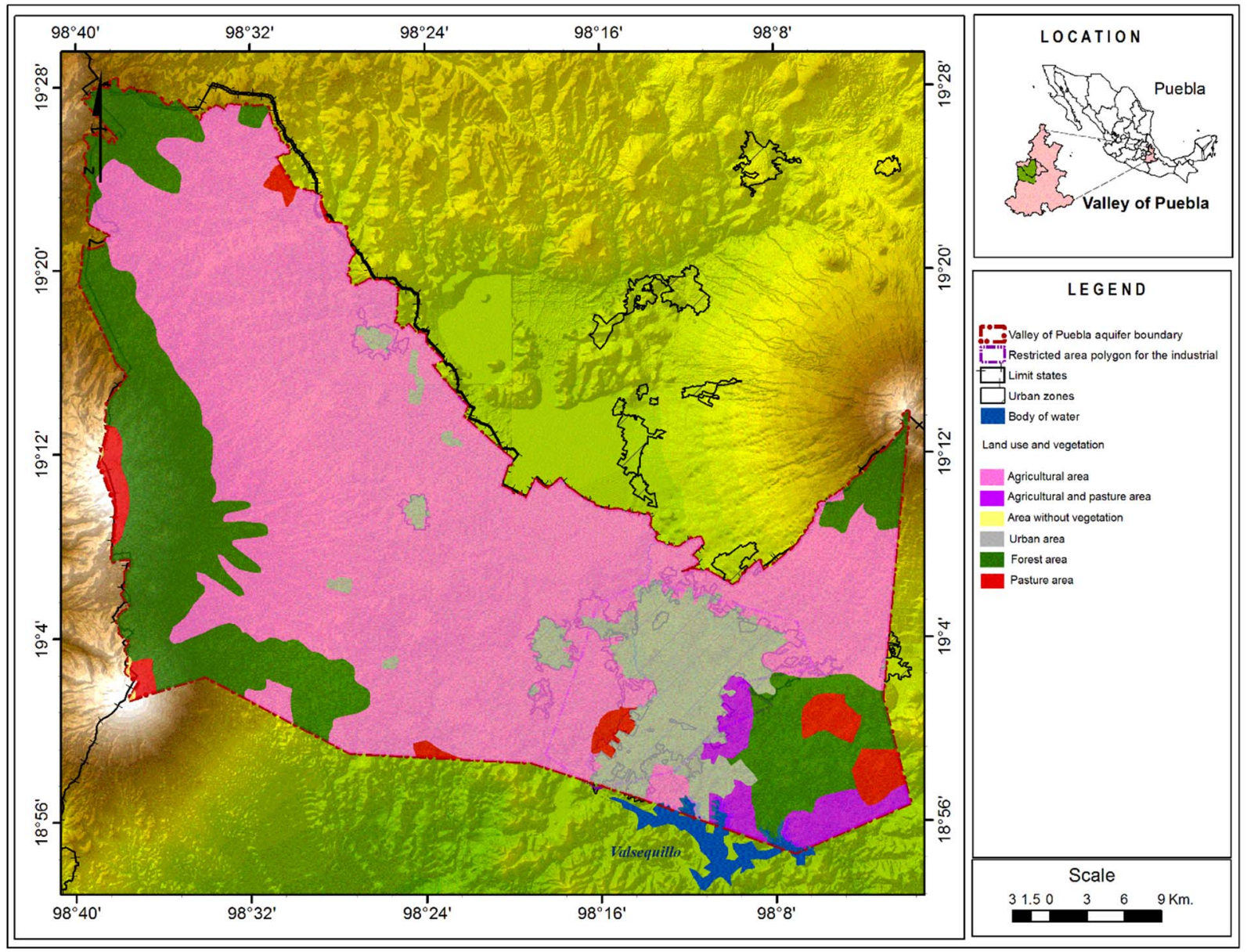

Fig. 2. Land use and vegetation cover in the Puebla Valley aquifer.

entirely met by groundwater (CONAGUA, 2015). Intensive extraction of groundwater has led to significant decline in groundwater levels in the urban area and water quality changes (Flores-Márquez et al., 2006; Gárfias et al., 2010; Salcedo-Sánchez et al., 2013). A large percentage of groundwater extraction is concentrated in this urban-industrial area (approximately 350 wells), where $85 \%$ of the state's industry is located. The main industries are basic metal, food, chemicals, electronics, pulp and paper industry while the textile, steelworks, tannery, paint and automotive industries are also important (Ayuntamiento de Puebla, 2014; INEGI, 2010).

\subsection{Hydrogeological setting}

The Puebla Valley aquifer is made up of an upper, middle and a deep aquifer (Fig. 3). The upper aquifer consists of granular deposits and fractured Quaternary rock formations. These sediments and rocks come from the surrounding volcanoes that produced lava flow, pyroclastic deposits and tuffs. This upper aquifer hydraulically functions as an unconfined aquifer, however in few localized areas can be semiconfined (Flores-Márquez et al., 2006; Salcedo-Sánchez et al., 2013). The hydraulic conductivity of this aquifer varies considerably, but their values in general are high. This hydrogeological unit overlies lacustrine deposits of Pliocene age, consisting of fine sediments (shale) with very low hydraulic conductivity. Therefore, the lacustrine deposits function as an aquitard between the upper and middle aquifer (Fig. 4).

The middle aquifer consists of andesites, basalts, ignimbritic tuffs and conglomerates of the Balsas Group. This aquifer is confined with middle to low hydraulic conductivities, due to its secondary permeability. This hydrogeological unit rest on an aquitard of the Mezcala Formation. Shales and interdigited marls and limestones form this aquitard. Even though, the composition of these rocks makes them almost impermeable in some fractured areas there is a vertical hydraulic connection between the middle and the deep aquifers (Gárfias et al., 2010; Salcedo-Sánchez et al., 2013).

The deep aquifer is composed mainly of limestone, sandstone and some shale layers of the Tecomasuchil and Atzompa Formations, and dolomite, sandstone, evaporites (gypsum) and shales of the Tecocoyunca Group of Cretaceous Age (Salcedo-Sánchez et al., 2013; Gárfias et al., 2010; Flores-Márquez et al., 2006). These units have experienced tectonic processes over time, resulting on folding and fracturing of the rocks, and therefore a secondary permeability.

Several processes contribute to upwelling mineralized water of the deep aquifer in the urban zone of Puebla Valley aquifer, such differences in hydraulic heads, the existence of a fault system that provide a route for a rising flow and the hydraulic connection produced by wells at different levels of the aquifer (Flores-Márquez et al., 2006). The mixing proportions of each type of water vary depending on factors such as the depth of the screen and the location of the well. For example, the difference of the effect on a well situated near faults and fractures is not the same as one positioned further away, nor is it the same for wells near drawdown areas and those located at distances further away.

Groundwater has been exploited in Puebla Valley aquifer, principally to meet the needs of the population and industry $(55.4 \%$ and $12.8 \%$ ), according to the groundwater balance, the total average annual recharge received by the aquifer is 360.7 Millions of $\mathrm{m}^{3}$ year ${ }^{-1}$ and distributed as shown in the Table 1 . The components of the water balance are presented according to those values reported by CONAGUA (DOF, 2016), with a "change of storage value" negative ( -28.2 Millions of $\mathrm{m}^{3}$ year ${ }^{-1}$ ), indicating that the extraction comes from a nonrenewable stored reservoir of the Puebla Valley aquifer (Table 2). 


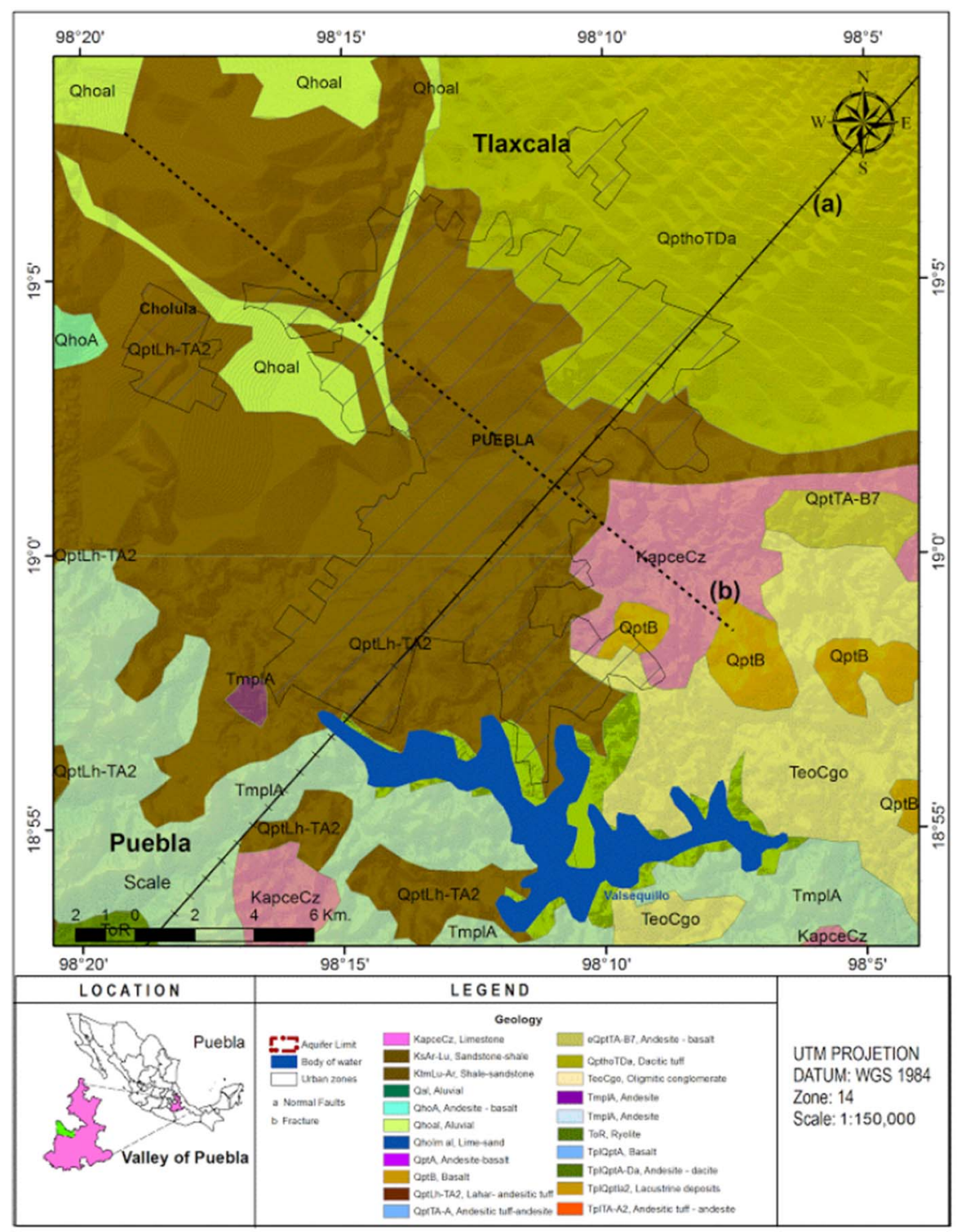

Fig. 3. Geological map and geological cross-section W-E of the Puebla Valley aquifer (Salcedo-Sánchez et al., 2016).

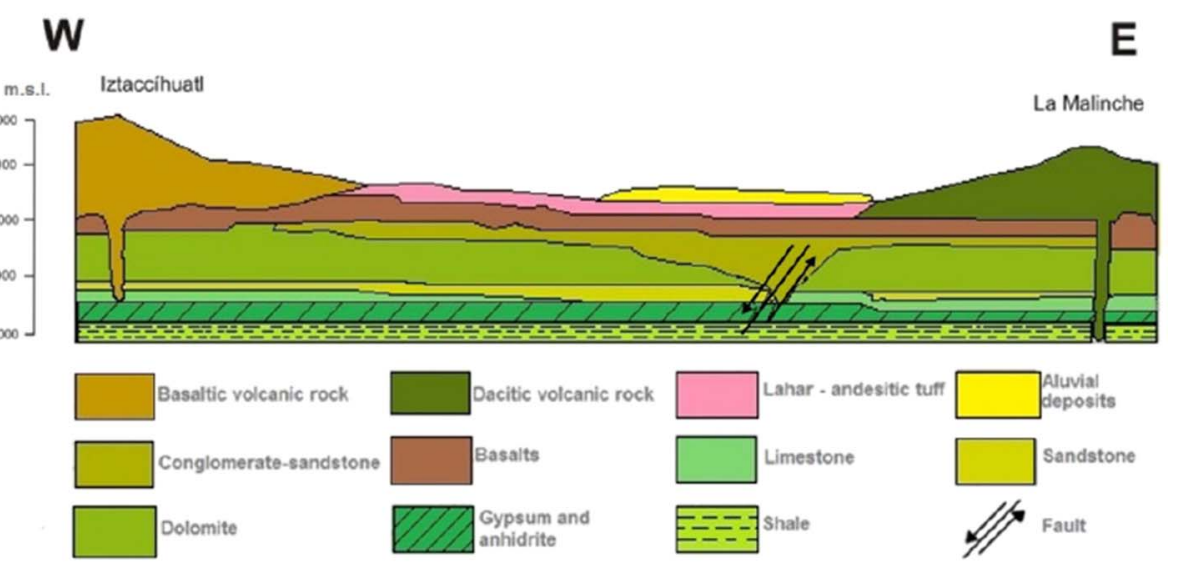

The groundwater head distribution for the upper aquifer shows two recharge zones, coming from Iztacchuatl and Popocatépetl volcanoes on the Western side of the valley and coming from the La Malinche Volcano on the Eastern side of the valley (Fig. 3). The former originates a groundwater flow with NW-SE direction, starting at the 2400 masl elevation, in the recharge area (Salcedo-Sánchez et al., 2013). The latter has a main component on the W-E direction, starting at about the 2230 masl elevation.

The recharge coming from the Tlaxcala State, at the North of the study area, has a main direction of NE-SW, corresponding to the 

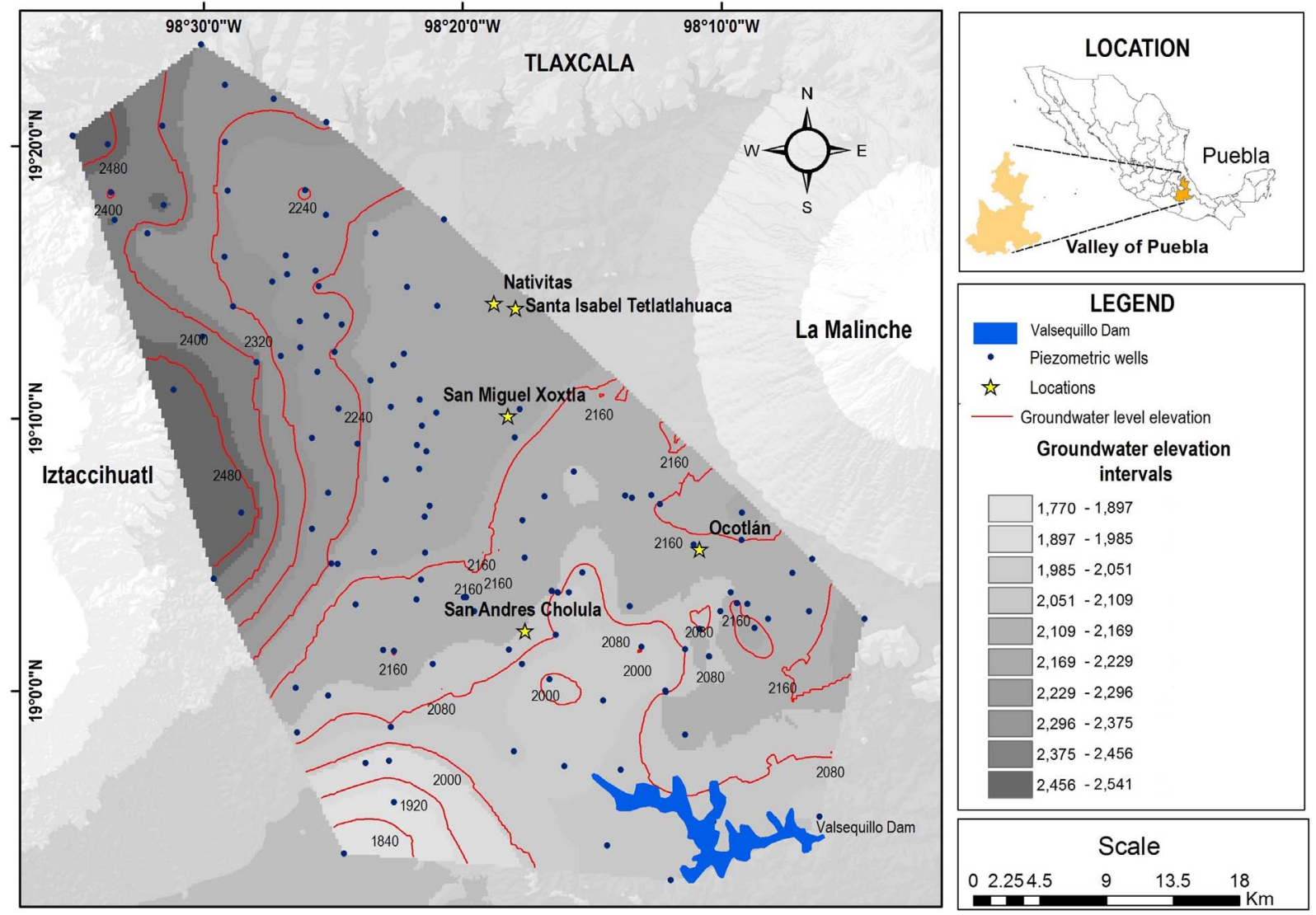

Fig. 4. Groundwater table level contour map (meters above sea level) for year 2012 of the Puebla Valley aquifer.

2300 mamsl elevation that matches the Zahuapan riverbed elevation. This groundwater flow joins the component from the Iztaccíhuatl and Popocatépetl volcanoes at Nativitas and Santa Isabel Tetlatlahuca, where the elevation curve is about 2190 masl. At Xoxtla and Ocotlán the flow takes a Western direction, and then the groundwater moves mainly towards the South, following the Atoyac river direction up the Valsequillo Dam at the end of the basin where the elevation curve is about 2040 masl (Salcedo-Sánchez et al., 2013; Fig. 3). The years of exploitation of the upper aquifer have developed a drawdown $2.5 \mathrm{~m} \mathrm{year}^{-1}$ in the urban area, encompassing the city of Puebla, San Andres Cholula and Necatitlán.

\section{Materials and methods}

Groundwater sampling was carried out in 20 drinking supply wells in November 2014, at shallow and deep aquifer, with total depth of 188 to $247 \mathrm{~m}$ (Table 1). The present study was conducted according to the authorization and guidelines for access to the supply wells of the Water Utilities Company "Consorcio de Agua de Puebla" in charge of the administration of the Potable Water System. The sampled wells were distributed throughout the urban area of Puebla City (Fig. 1).

The rainfall during the sampled campaign was about $16.25 \mathrm{~mm}$ (SMN, 2017), therefore, it is very unlikely that the rain would have any short-term effect on the geochemistry of the water samples.

In order to determine field and laboratory parameters, water was collected in plastic containers, which were appropriately washed in the laboratory. Different Hanna 9828 CB-29586 multi-parametric electrode probes were inserted to read water temperature, redox potential (Eh), $\mathrm{pH}$, total dissolved solids (TDS) and electrical conductivity (EC).

The water samples were collected according to existing protocols detailed in norm NOM-230-SSA1-2002 (DOF, 2003) which conformed to APHA, AWW and WEF guidelines (2005). Two water samples were taken, one to analyze anions, and other to cations and heavy metals; the sample of cations and heavy metals was preserved with nitric acid until reaching a $\mathrm{pH}$ less than or equal to 2 . A third sample for each site were taken for total hardness. All the samples were stored in refrigeration $\left(4{ }^{\circ} \mathrm{C}\right)$ until analyzed. The parameters presented in Table 3 were determined in the laboratory.

Determinations by Inductively Coupled Plasma Emission Spectrometry (ICP-OES) and Liquid Chromatography high performance (HPLC) were carried out at the Laboratory of Geosciences at the National Autonomous University of Mexico. The rest of the samples were analyzed by conventional techniques in the Water Quality Laboratory of the Mexican Institute of Water Technology (IMTA).

Likewise, the Piper diagram has been used to define the different hydrochemical groups using AquaChem 4.0 software (Waterloo Hydrogeologic, 1999). To examine which minerals can dissolve or precipitate within the aquifer systems, the saturation state of groundwater with respect to selected mineral phases was computed using Geochemist's Workbench (GWB) (Aqueous Solutions, 2016) and PHREEQC software for speciation ions (Parkhurst and Appelo, 1999). Information on mineral saturation states is useful for interpreting mineral controls on ion concentrations and hypothesizing probable reactions (Appelo and Postma, 2005).

The correlation coefficients were applied to detect the relationship of physicochemical parameters, major ions and trace elements. A factor analysis of cluster was also performed to better understand the sources of the hydrochemical species and to identify the most significant factors in the water-rock interaction process. The calculations were performed using STADISTICA 10 software (StatSoft, 2011). 





Table 2

Components of the groundwater balance (units in Millions of $\mathrm{m}^{3}$ year $^{-1}$ ) (DOF, 2016).

\begin{tabular}{lllllllll}
\hline Inflow & \multicolumn{1}{c}{} & \multicolumn{4}{c}{ Outflow } & & \multicolumn{2}{c}{ Change of storage } \\
\hline Ih & Iv & Ir & Total & Sh & Spr & Db & Total & $\Delta$ S \\
196.8 & 116.5 & 47.4 & 360.7 & 42.2 & 19.0 & 327.7 & 388.9 & -28.2
\end{tabular}

Ih horizontal inflows, $I v$ vertical infiltration, Ir return flows, $S h$ horizontal outflows, Spr springs, $D b$ extraction by deep wells, $\Delta S$ change in storage.

\section{Results and discussion}

\subsection{Chemical composition of groundwater}

Physicochemical data of groundwater samples were statistically analyzed and the results were summarized in the Table 4 . The electrical conductivity (EC) indicates the dissolved material in water and its values range 312 to $3340 \mu \mathrm{sm}^{-1}$, and mean of $1431 \mu \mathrm{S} \mathrm{cm}{ }^{-1}$; these reported values indicate high concentrations of dissolved material. The concentration of $\mathrm{Ca}^{2+}, \mathrm{Mg}^{2+}, \mathrm{K}^{+}$and $\mathrm{Na}^{+}$ions ranged from 28.74 to 431.2, 6.53 to $110,1.36$ to 30.1 and 5.07 to $135.8 \mathrm{mg} \mathrm{L}^{-1}$ with a mean of $156.1,52.9,13.7$ and $52.9 \mathrm{mg} \mathrm{L}^{-1}$ respectively. The order of abundance is $\mathrm{Ca}^{2+}>\mathrm{Mg}^{2+}>\mathrm{Na}^{+}>\mathrm{K}^{+}$.

Among the anions, the concentrations of $\mathrm{HCO}_{3}{ }^{-}, \mathrm{Cl}^{-}, \mathrm{SO}_{4}{ }^{2-}$ and $\mathrm{NO}_{3}{ }^{-}$ions lie between 105 and $1155,4.84$ to $107.4,10.8$ to 760 and 0.5 to $42.23 \mathrm{mg} \mathrm{L}^{-1}$ with a mean of $707.7,39.5,160.5$ and $13.8 \mathrm{mg} \mathrm{L}^{-1}$, respectively. The order of their abundance is $\mathrm{HCO}_{3}^{-}>\mathrm{SO}_{4}{ }^{2-}>\mathrm{Cl}^{-}>\mathrm{NO}_{3}{ }^{-}$.

The major ions represent $99 \%$ of the total concentration of each sample. The anions $\mathrm{HCO}_{3}{ }^{-}, \mathrm{Cl}^{-}, \mathrm{SO}_{4}{ }^{2-}$ and $\mathrm{NO}_{3}{ }^{-}$represent between 72 and $78 \%$, while for cations $\mathrm{Ca}^{2+}, \mathrm{Mg}^{2+}, \mathrm{K}^{+}$and $\mathrm{Na}^{+}$the percentage varies from 20 to $28 \%$, and $<1 \%$ correspond to minor ions and trace elements.

Water quality was evaluated according to criteria established for human consumption by the World Health Organization (WHO, 2008) and criteria established for human use and consumption by Mexican standards NOM-127-SSA1-1994 (DOF, 2004) (Table 4).

Based on Mexican standards, the value of $\mathrm{pH}$ was found in almost all wells below the range defined by such regulation (6.5-8.5) except wells 2,4 and 8 (6.31, 6.24 and 5.48); indicating that the $\mathrm{pH}$ of water samples is well under the desirable limit. The TDS ranged from 260 to $2860 \mathrm{mg} \mathrm{L}^{-1}$, wells $2,3,4,5,6,7,8,18$ and 19 exceed the limit value set in the Mexican standard and the WHO criteria of $1000 \mathrm{mg} \mathrm{L}^{-1}$. The sulphate $\left(\mathrm{SO}_{4}{ }^{2-}\right)$ concentration varies widely in the monitored wells (10.8 to $760 \mathrm{mg} \mathrm{L}^{-1}$ ), wells 3,8 and 19 exceed the limit of $400 \mathrm{mg} \mathrm{L}^{-1}$ of the Mexican standards and wells 3 and 7 exceed the limit $250 \mathrm{mg} \mathrm{L}^{-1}$ established by WHO. Chloride ion imparts a salty taste to water, in the present study $\mathrm{Cl}^{-}$ranging concentrations from 4.87 to $107 \mathrm{mg} \mathrm{L}^{-1}$, all values under the limits of the WHO criteria $\left(250 \mathrm{mg} \mathrm{L}^{-1}\right)$. Nitrates is the most common form for nitrogen in groundwater; $\mathrm{NO}_{3}{ }^{-}$is very soluble and mobile. The nitrate in the samples was below the established limit by the Mexican standards (44 $\mathrm{mg} \mathrm{L}^{-1}$ ) and WHO criteria of $50 \mathrm{mg} \mathrm{L}^{-1}$ (Table 4).

For all the wells, sodium concentrations were below the limit of $200 \mathrm{mg} \mathrm{L}^{-1}$ established by the WHO and calcium and magnesium concentrations exceeded WHO criteria $\left(75 \mathrm{mg} \mathrm{L}^{-1}\right.$ and $30 \mathrm{mg} \mathrm{L}^{-1}$, respectively). In almost all the wells, total hardness values surpassed the limit established by Mexican standard of $500 \mathrm{mg} \mathrm{L}^{-1}$ and for all the cases the WHO criteria of $100 \mathrm{mg} \mathrm{L}^{-1}$ (Table 4).

The majority of the collected samples in the study area show detectable concentrations of $\mathrm{Fe}, \mathrm{Mn}, \mathrm{F}, \mathrm{Ba}, \mathrm{Sr}, \mathrm{Cu}, \mathrm{B}, \mathrm{Li}$ and $\mathrm{Zn}$. For the other analyzed elements during the sample campaign, such as phosphate, $\mathrm{Al}, \mathrm{As}, \mathrm{Be}, \mathrm{Bi}, \mathrm{Cr}, \mathrm{Sb}, \mathrm{Sn}, \mathrm{Tl}$ and $\mathrm{Mo}$; their concentrations were under the detection limit for the analytical method used.

Iron $(\mathrm{Fe})$ is an essential element in human nutrition. Estimates of the minimum daily requirement for iron depend on age, sex, physiological status, and iron bioavailability and range from about 10 to $50 \mathrm{mg} \mathrm{day}^{-1}$ (WHO, 2003a, 2003b). Iron concentration in the sample wells varies widely in the monitored wells $\left(0.001\right.$ to $\left.0.38 \mathrm{mg} \mathrm{L}^{-1}\right)$, except in the well 7 where iron exceed both limits WHO and Mexican standards $\left(0.30 \mathrm{mg} \mathrm{L}^{-1}\right)$.

Manganese is one of the more abundant metallic elements in the Earth; it is present in igneous and metamorphic rocks as a minor constituent. In the Puebla Valley aquifer, Mn is a significant constituent of basalt, and small amounts are present in dolomite and limestone, substituting the calcium (Hem, 1992). High exposure to Mn has been associated with toxicity, causing health problems (WHO, 2011a, 2011b). In five of the wells, Mn was found above the established limit by the Mexican standards ( $0.15 \mathrm{mg} \mathrm{L}^{-1}$; wells 2, 3, 4, 5 and 6) and in four wells (2, 3, 4 and 5) for to WHO criteria of $0.4 \mathrm{mg} \mathrm{L}^{-1}$.

Barium (Ba) concentration ranged from 0.009 to $0.304 \mathrm{mg} \mathrm{L}^{-1}$, in all the wells it was below the limit value set in the Mexican standards and the WHO criteria $\left(0.7 \mathrm{mg} \mathrm{L}^{-1}\right)$. Ba comes primarily from geogenic sources (WHO, 2003a, 2003b). Ba is not considered an essential element for human nutrition, in moderate to large concentrations can cause death; and smaller concentrations can cause damage to the heart, blood vessels, and nerves (Table 4).

In the urban area of Puebla Valley aquifer, the Boron (B) concentration ranges from to 0.11 to $2.16 \mathrm{mg} \mathrm{L}^{-1}$. These concentrations may represent a potential risk to the health of the population if these sources are used for human consumption (WHO, 2008, 2010). B is an element that can be present in groundwater, it is common in areas of thermal springs and volcanic zones, and can enter in two main ways: weathering of rocks containing boron and wastewater where boron is derived from cleaning products and waste paint industries and varnishes, textiles, leather tanning, and electronics, among others (Hem, 1992; Morell et al., 2008; Dyer and Caprara, 2009).

The $\mathrm{F}^{-}$ranged from 0.08 to $1.43 \mathrm{mg} \mathrm{L}^{-1}$, the concentrations for all wells were below the limit value set in the Mexican standards and the WHO criteria of $1.5 \mathrm{mg} \mathrm{L}^{-1}$, and the concentration of well 8 is almost within the criteria $\left(1.43 \mathrm{mg} \mathrm{L}^{-1}\right)$. For $\mathrm{Zn}$ and $\mathrm{Cu}$ values were below the limit established by the Mexican standards $\left(5 \mathrm{mg} \mathrm{L}^{-1}\right.$ for $\mathrm{Zn}$ and $2 \mathrm{mg} \mathrm{L}^{-1}$ for $\mathrm{Cu}$ ) and WHO criteria $\left(3 \mathrm{mg} \mathrm{L}^{-1}\right.$ for $\mathrm{Zn}$ and $2 \mathrm{mg} \mathrm{L}^{-1}$ for $\mathrm{Cu}$ ). In the all wells, Strontium (Sr) concentrations were below of the lifetime health advisory of the US Environmental Protection Agency (EPA, 2007) of $4 \mathrm{mg} \mathrm{L}^{-1}$.

\subsection{Hydrochemical facies}

Based on the relative dominance of major cations and anions in terms of their reacting values, four types of hydrochemical facies have been identified in the urban area of Puebla City (Fig. 5), as follows: 1) calcium bicarbonate $\left(\mathrm{Ca}-\mathrm{HCO}_{3}\right.$, in nine wells), this waters originate

Table 3

Quantified parameters and analytical techniques.

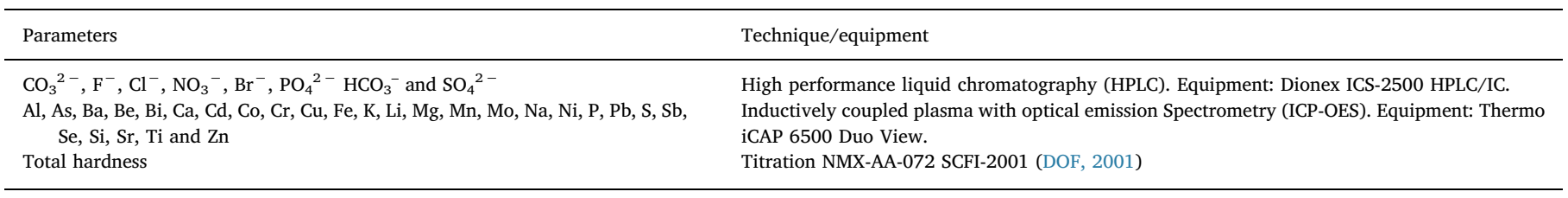




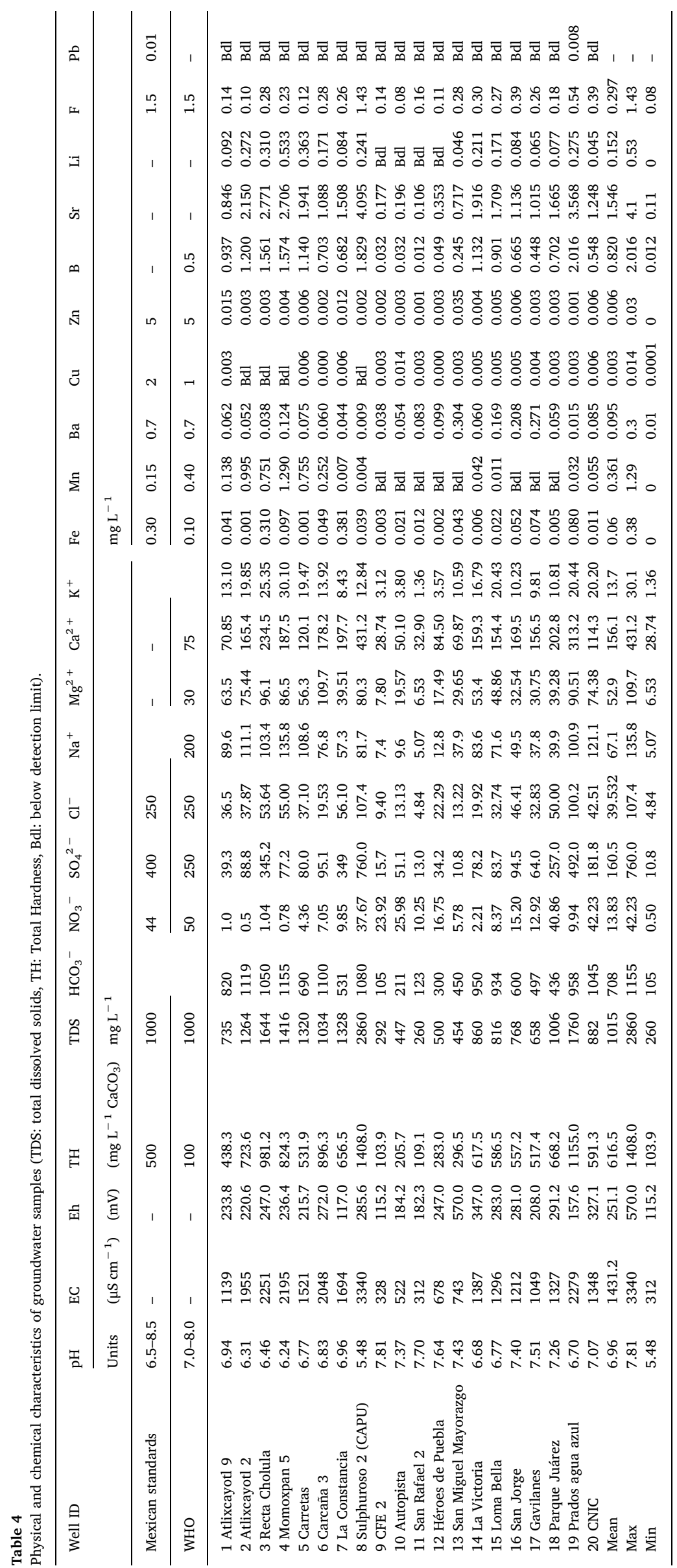




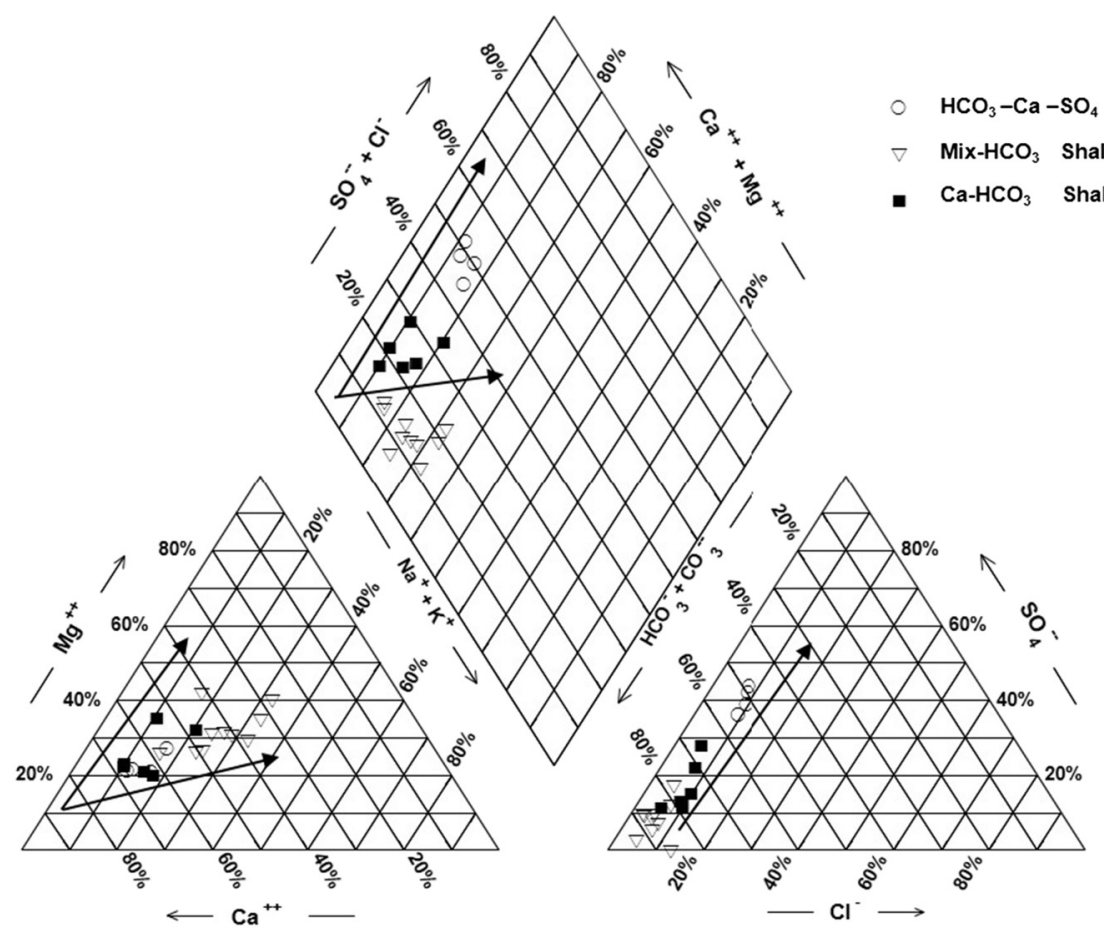

\section{LEGEND}

Fig. 5. Piper diagram of chemical data in the study area.

Table 5

The correlation matrix among the chemical constituents for groundwater samples (coefficients higher than 0.07 were shown as bold fonts).

\begin{tabular}{|c|c|c|c|c|c|c|c|c|c|c|c|c|c|c|c|c|c|c|c|}
\hline & $\mathrm{pH}$ & EC & $\mathrm{HCO}_{3}{ }^{-}$ & TDS & $\mathrm{NO}_{3}{ }^{-}$ & $\mathrm{SO}_{4}{ }^{2-}$ & $\mathrm{Cl}^{-}$ & $\mathrm{Na}^{2+}$ & $\mathrm{Mg}^{2+}$ & $\mathrm{Ca}^{2+}$ & $\mathrm{K}^{+}$ & $\mathrm{Fe}$ & Mn & $\mathrm{Ba}$ & $\mathrm{Cu}$ & $\mathrm{Zn}$ & B & $\mathrm{Sr}$ & $\mathrm{Li}$ \\
\hline $\mathrm{pH}$ & 1.00 & & & & & & & & & & & & & & & & & & \\
\hline EC & -0.92 & 1.00 & & & & & & & & & & & & & & & & & \\
\hline $\mathrm{HCO}_{3}{ }^{-}$ & -0.84 & 0.82 & 1.00 & & & & & & & & & & & & & & & & \\
\hline TDS & -0.89 & 0.96 & 0.67 & 1.00 & & & & & & & & & & & & & & & \\
\hline $\mathrm{NO}_{3}{ }^{-}$ & 0.12 & -0.03 & -0.24 & 0.09 & 1.00 & & & & & & & & & & & & & & \\
\hline $\mathrm{SO}_{4}^{2-}$ & -0.65 & 0.79 & 0.40 & 0.89 & 0.36 & 1.00 & & & & & & & & & & & & & \\
\hline $\mathrm{Cl}-$ & -0.70 & 0.83 & 0.54 & 0.90 & 0.21 & 0.90 & 1.00 & & & & & & & & & & & & \\
\hline $\mathrm{Na}^{2+}$ & -0.76 & 0.72 & 0.91 & 0.61 & -0.27 & 0.30 & 0.52 & 1.00 & & & & & & & & & & & \\
\hline $\mathrm{Mg}^{2+}$ & -0.78 & 0.84 & 0.93 & 0.70 & -0.21 & 0.47 & 0.56 & 0.85 & 1.00 & & & & & & & & & & \\
\hline $\mathrm{Ca}^{2+}$ & -0.78 & 0.92 & 0.62 & 0.93 & 0.16 & 0.91 & 0.91 & 0.47 & 0.63 & 1.00 & & & & & & & & & \\
\hline $\mathrm{K}^{+}$ & -0.70 & 0.66 & 0.87 & 0.53 & -0.34 & 0.23 & 0.45 & 0.93 & 0.80 & 0.45 & 1.00 & & & & & & & & \\
\hline $\mathrm{Fe}$ & -0.19 & 0.33 & 0.14 & 0.32 & -0.26 & 0.37 & 0.31 & 0.17 & 0.23 & 0.30 & 0.19 & 1.00 & & & & & & & \\
\hline Mn & -0.27 & 0.14 & 0.34 & 0.03 & -0.48 & -0.35 & -0.15 & 0.71 & 0.30 & -0.17 & 0.70 & 0.01 & 1.00 & & & & & & \\
\hline $\mathrm{Ba}$ & 0.39 & -0.37 & -0.20 & -0.43 & -0.18 & -0.46 & -0.33 & -0.22 & -0.34 & -0.30 & -0.08 & -0.13 & 0.20 & 1.00 & & & & & \\
\hline $\mathrm{Cu}$ & 0.35 & 0.14 & -0.40 & -0.36 & 0.24 & -0.22 & -0.27 & -0.29 & -0.43 & -0.37 & -0.30 & -0.06 & -0.48 & 0.06 & 1.00 & & & & \\
\hline $\mathrm{Zn}$ & 0.17 & -0.22 & -0.12 & -0.23 & -0.24 & -0.22 & -0.20 & -0.05 & -0.16 & -0.27 & -0.06 & 0.13 & -0.21 & 0.55 & 0.06 & 1.00 & & & \\
\hline B & -0.87 & 0.89 & 0.81 & 0.87 & -0.23 & 0.67 & 0.82 & 0.80 & 0.80 & 0.82 & 0.78 & 0.25 & 0.25 & -0.36 & -0.38 & -0.20 & 1.00 & & \\
\hline $\mathrm{Sr}$ & -0.88 & 0.93 & 0.74 & 0.94 & -0.03 & 0.80 & 0.88 & 0.70 & 0.72 & 0.91 & 0.70 & 0.25 & 0.13 & -0.34 & -0.38 & -0.23 & 0.96 & 1.00 & \\
\hline $\mathrm{Li}$ & -0.77 & 0.72 & 0.73 & 0.65 & -0.44 & 0.29 & 0.49 & 0.81 & 0.72 & 0.52 & 0.86 & 0.18 & 0.80 & -0.21 & -0.38 & -0.19 & 0.83 & 0.77 & 1.00 \\
\hline
\end{tabular}

from rapid groundwater flow path and low residence time; 2) mixed bicarbonate (Mix- $\mathrm{HCO}_{3}$, nine wells), correspond to mixing waters which have relatively longer circulation flow paths and high ion content; 3) calcic sulphated bicarbonate $\left(\mathrm{HCO}_{3}-\mathrm{Ca}-\mathrm{SO}_{4}\right.$, one well), and 4) calcium sulphated water $\left(\mathrm{SO}_{4}-\mathrm{Ca}\right.$, one well), correspond to old waters which have deep circulation within aquifers, having very high ion content due to prolonged contact with rocks. These type of waters have highest TDS values among all waters samples, cation are dominated by $\mathrm{Ca}^{2+}$ and $\mathrm{Mg}^{2+}$ and the anions are dominated by $\mathrm{SO}_{4}{ }^{2-}$.

Mix- $\mathrm{HCO}_{3}$ waters show a tendency towards a $\mathrm{Ca}-\mathrm{Mg}-\mathrm{HCO}_{3}$ composition, with a trend of increased sulphate probably from dissolution of calcite, dolomite and gypsum. Waters within the deep wells are predominantly rich in $\mathrm{SO}_{4}{ }^{2-}, \mathrm{Mg}^{2+}, \mathrm{Ca}^{2+}$, and other ionic solutes from the substratum (Fig. 5).

The chemical tendencies observed in the shallow and deep groundwater are the consequence of processes that change the chemistry of water along the direction of flow and hydrogeology of each rock unit.

\subsection{The origin of the solutes}

Correlations between dissolved species can reveal the origin of solutes and the process that generated the observed water compositions (Jalali and Jalali, 2016). Direct correlation exists when an increase or decrease in the value of one parameter is associated with a corresponding increase or decrease in the value of other parameter (GueyShin et al., 2011). The correlation coefficient matrix for the chemical parameters is shown in Table 4. If the correlation coefficient ( $r$ ) is $>0.7$, two parameters are considered to be strongly correlated, whereas if the value $r$ is between 0.5 and 0.7 , it indicates a moderate correlation at a significance level $p \backslash 0.05$ (Guey-Shin et al., 2011).

Parameters having high correlations are EC and TDS $(r=0.96)$ 


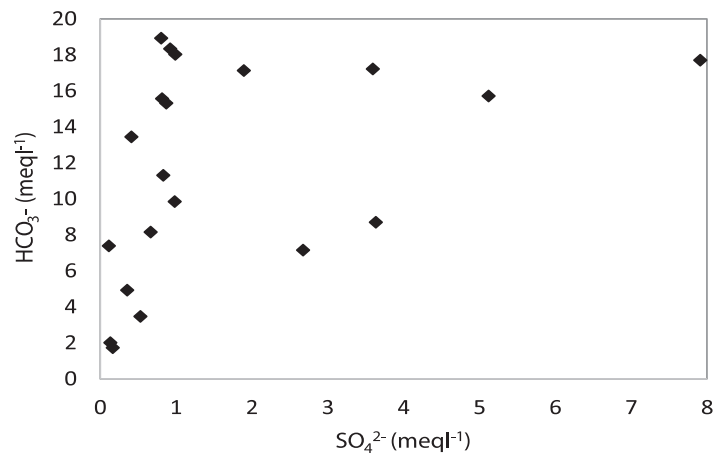

(a)

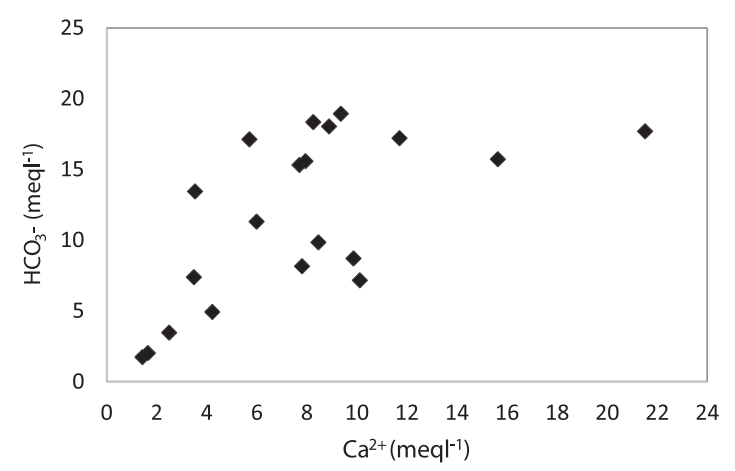

(c)

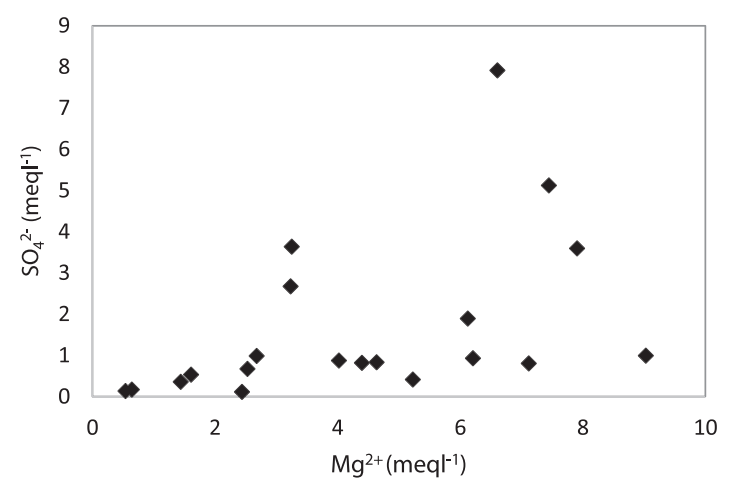

(e)
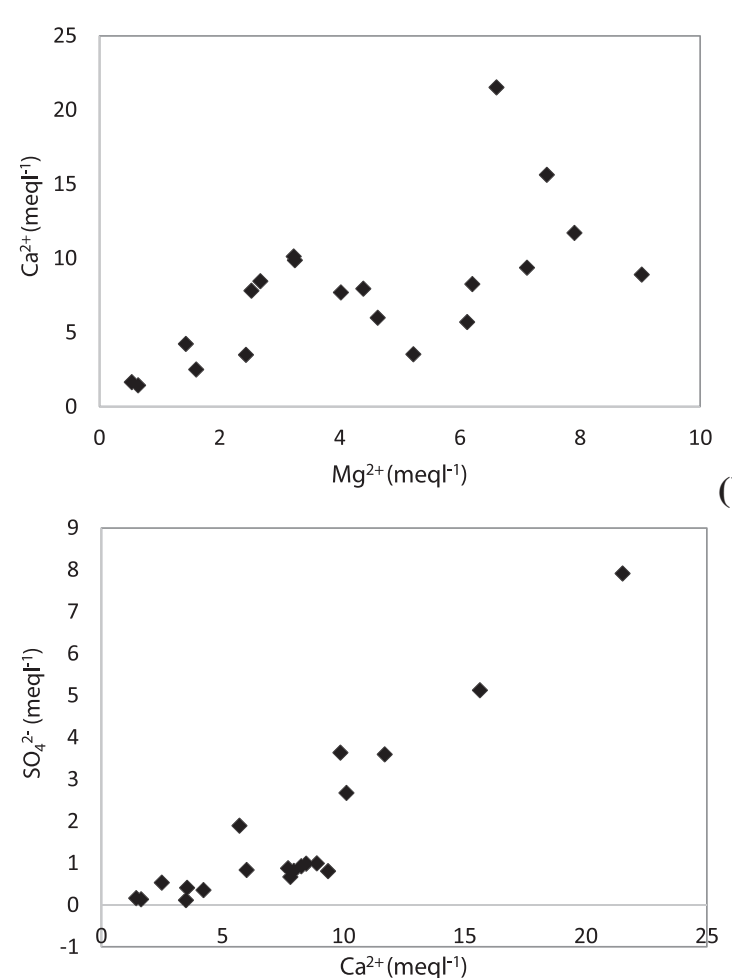

(d)

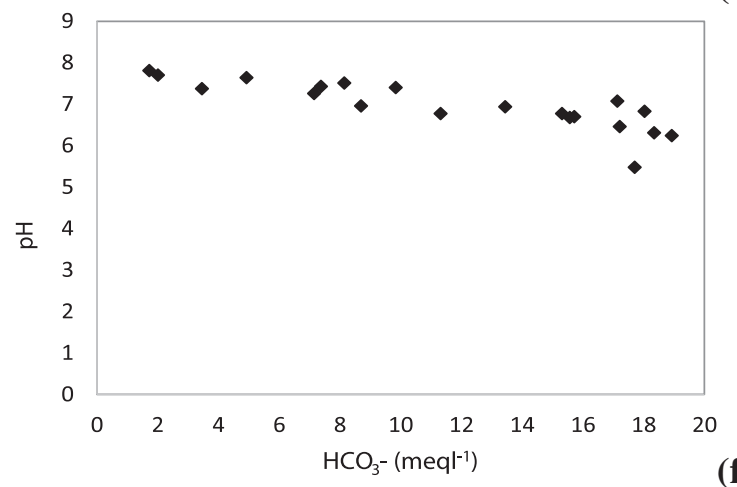

Fig. 6. Relations between ion concentration for $\mathrm{SO}_{4}{ }^{2+}, \mathrm{Ca}^{2+}, \mathrm{Mg}^{2+}, \mathrm{HCO}_{3}{ }^{-}, \mathrm{Cl}^{-}$and $\mathrm{pH}$.

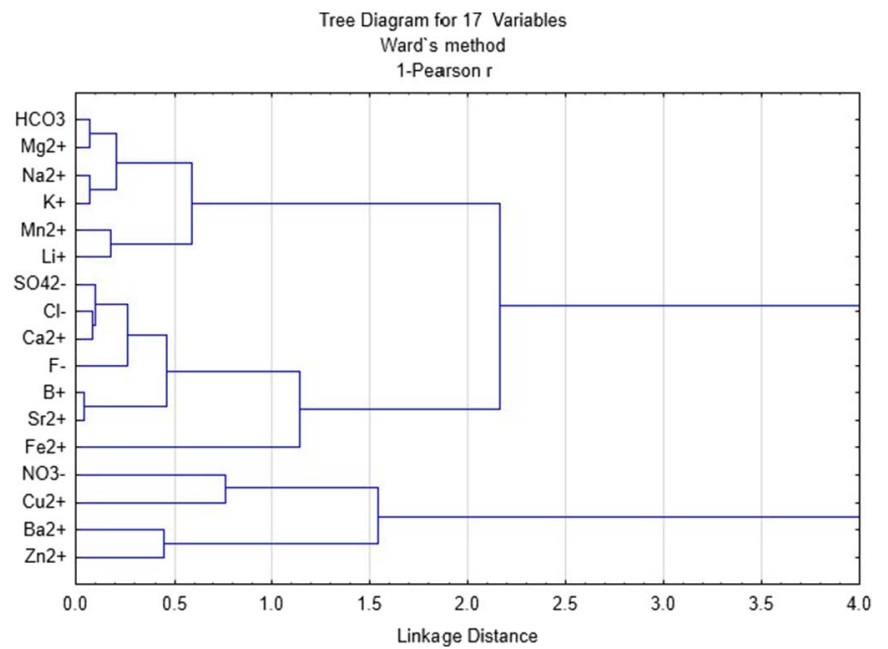

Fig. 7. Dendrogram of water quality parameters.

because all of the dissolved components cause an increased ionic concentration, as well as increased EC measure (Table 5). EC and TDS are highly related to $\mathrm{SO}_{4}{ }^{2-}(\mathrm{r}=0.89), \mathrm{Ca}^{2+}(\mathrm{r}=0.93)$ and $\mathrm{Cl}^{-}$ $(\mathrm{r}=0.90)$ but moderately related to $\mathrm{Mg}^{2+}(\mathrm{r}=0.70), \mathrm{Na}^{+}(\mathrm{r}=0.61)$ and $\mathrm{K}^{+}(\mathrm{r}=0.53) . \mathrm{Na}^{2+}$ and $\mathrm{Cl}^{-}$also have positive correlation $(\mathrm{r}=0.52)$. The relation is not apparent in comparison to $\mathrm{Cl}^{-}$versus sulphate waters $(r=0.90)$. This relation was scattered (Fig. 6a) indicating a different source of chloride for high and low sulphate concentrations.

$\mathrm{Ca}^{2+}$ and $\mathrm{Mg}^{2+}$ presented positive correlation $(\mathrm{r}=0.63$; Table 5 and Fig. $6 \mathrm{~b}$ ) indicating a common source. It could be predictable that a great part of $\mathrm{HCO}_{3}{ }^{-}$originated from dissolution of carbonate rocks. The dissolution of carbonate releases $\mathrm{Ca}^{2+}$ into solution, producing water type $\mathrm{Ca}-\mathrm{HCO}_{3}$ (Fig. 5). The correlation coefficient between $\mathrm{Ca}^{2+}$ and $\mathrm{HCO}_{3}{ }^{-}$is moderate $(\mathrm{r}=0.62$, Fig. $6 \mathrm{c}$ ), and indicates calcite is the source of bicarbonates. Incongruent dissolution of dolomite is a rule in aquifers containing limestones, dolostones (dolomite-type carbonate rocks) and gypsiferous rocks (or anhydrite).

The increase in $\mathrm{Ca}^{2+}$ concentration in water, caused by gypsum dissolution provokes calcite precipitation by the common effect, this process known as dedolomitization and it is written as follows (Baldassare et al., 2011; Appelo and Postma, 2005; Sacks et al., 1995):

$1.8 \mathrm{CaSO}_{4}+0.8 \mathrm{CaMgCO}_{3(\mathrm{~s})} \rightarrow 1.6 \mathrm{CaCO}_{3(\mathrm{~s})}+\mathrm{Ca}^{2+}+0.8 \mathrm{Mg}^{2+}+1.8 \mathrm{SO}_{4}{ }^{2-}$ 


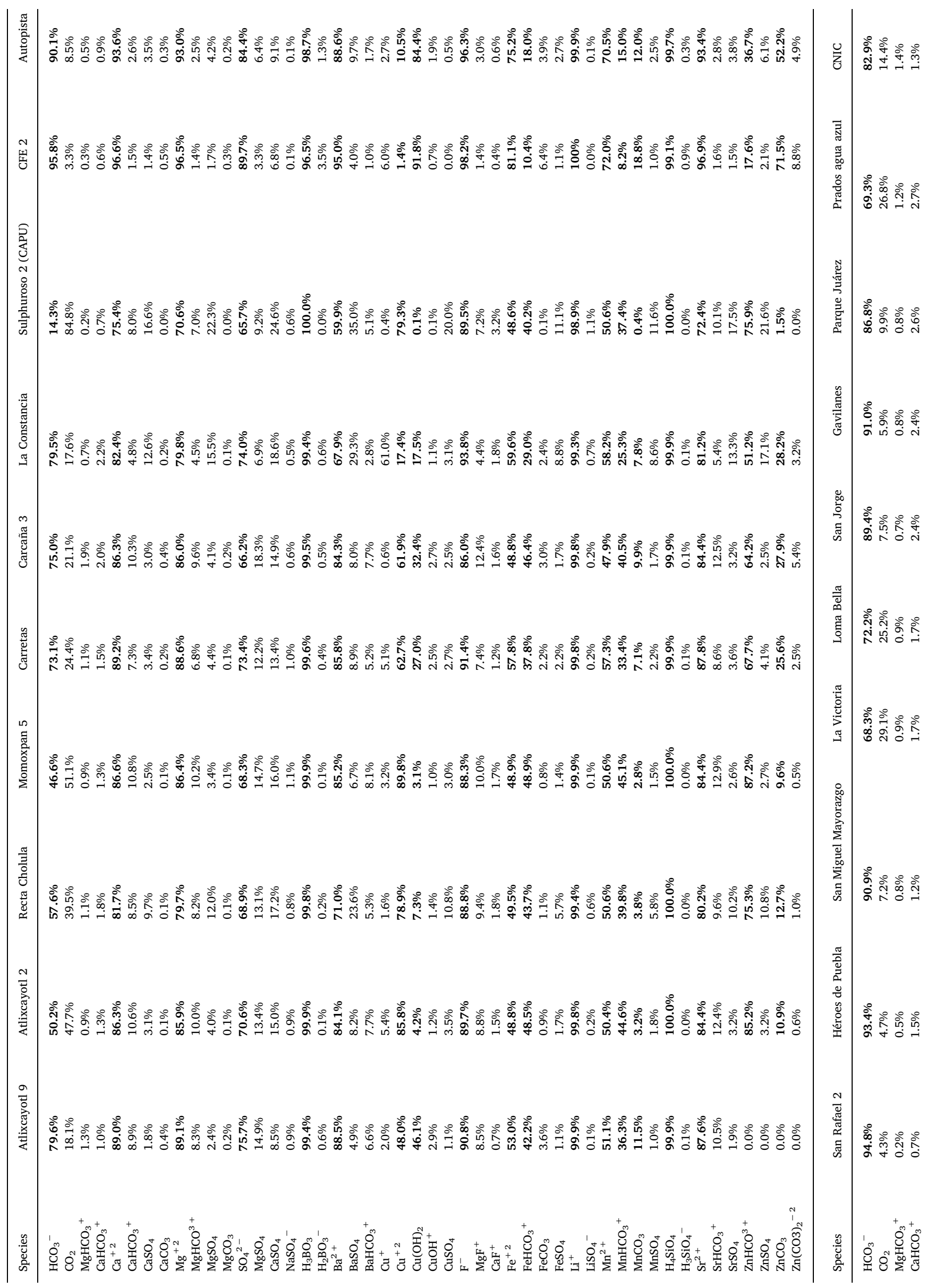




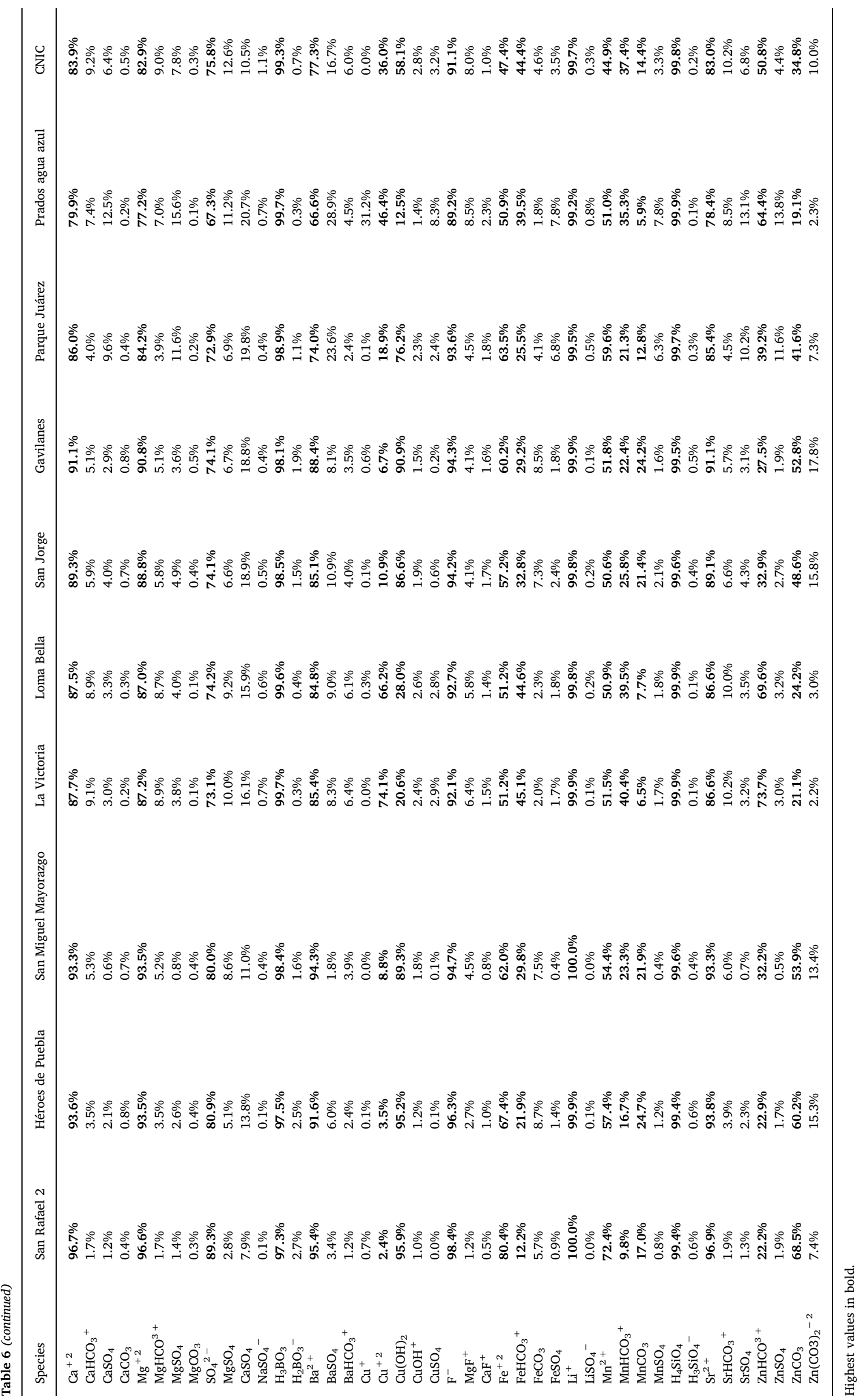



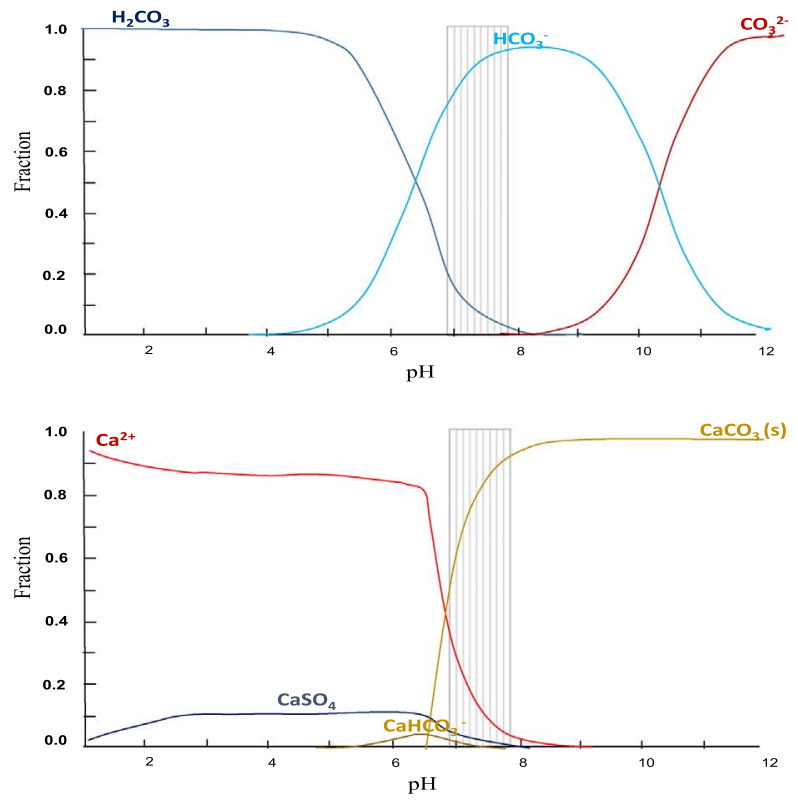
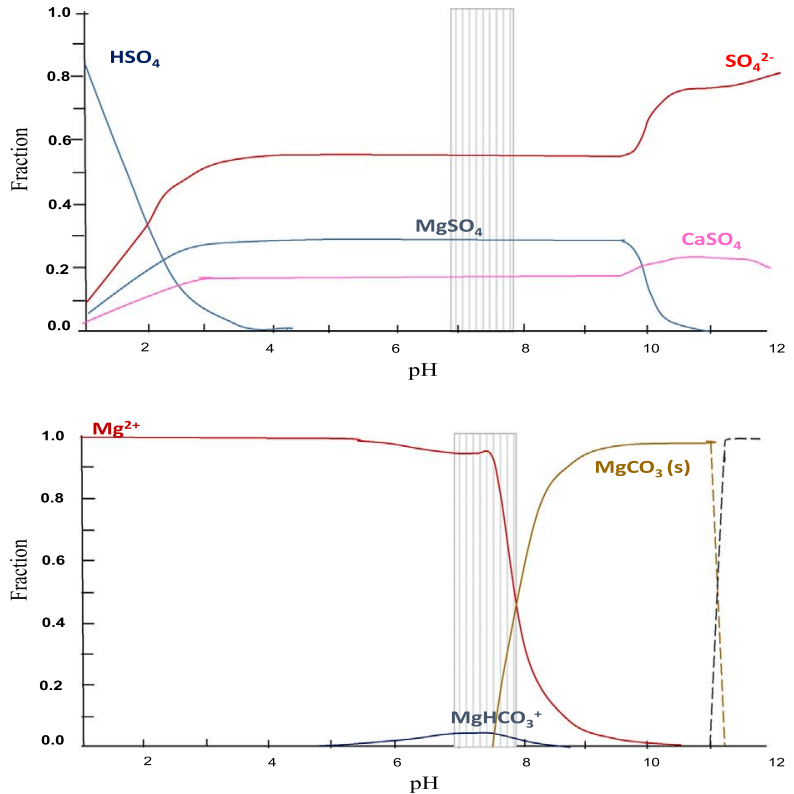

Fig. 8. Speciation diagrams for $\mathrm{HCO}_{3}{ }^{-}, \mathrm{SO}_{4}{ }^{2-}, \mathrm{Ca}^{2+}, \mathrm{Mg}^{2+}$ vs $\mathrm{pH}$.

Table 7

Summary of saturation indices.

\begin{tabular}{|c|c|c|c|c|c|}
\hline & \multirow[t]{2}{*}{ Well ID } & \multicolumn{4}{|c|}{ Saturation index } \\
\hline & & Calcite & Gypsum & Dolomite-dis & Dolomite-crys \\
\hline 1 & Atlixcayotl 9 & 0.169 & -2.295 & -0.103 & 1.443 \\
\hline 2 & Atlixcayotl 2 & -0.206 & -1.669 & -1.151 & 0.398 \\
\hline 3 & Recta Cholula & 0.025 & -1.034 & -0.759 & 0.807 \\
\hline 4 & Momoxpan 5 & -0.233 & -1.706 & -1.186 & 0.355 \\
\hline 5 & Carretas & 0.104 & -1.790 & -0.518 & 1.029 \\
\hline 6 & Carcaña 3 & 0.511 & -1.667 & 0.438 & 1.976 \\
\hline 7 & La Constancia & 0.334 & -1.015 & -0.456 & 1.110 \\
\hline 8 & Sulphuroso 2 (CAPU) & -1.263 & -0.533 & -3.594 & -2.073 \\
\hline 9 & CFE 2 & -0.061 & -2.776 & -1.161 & 0.417 \\
\hline 10 & Autopista & -0.055 & -2.139 & -0.995 & 0.588 \\
\hline 11 & San Rafael 2 & -0.066 & -2.802 & -1.323 & 0.263 \\
\hline 12 & Heroes de Puebla & 0.589 & -2.142 & 0.024 & 1.606 \\
\hline 13 & San Miguel Mayorazgo & 0.471 & -2.749 & 0.122 & 1.692 \\
\hline 14 & La Victoria & 0.186 & -1.709 & -0.539 & 1.030 \\
\hline 15 & Loma Bella & 0.271 & -1.687 & -0.400 & 1.173 \\
\hline 16 & San Jorge & 0.849 & -1.572 & 0.528 & 2.106 \\
\hline 17 & Gavilanes & 0.874 & -1.743 & 0.586 & 2.164 \\
\hline 18 & Parque Juárez & 0.603 & -1.112 & 0.044 & 1.621 \\
\hline 19 & Prados agua azul & 0.408 & -0.815 & -0.130 & 1.431 \\
\hline \multirow[t]{4}{*}{20} & CNIC & 0.502 & -1.529 & 0.381 & 1.955 \\
\hline & $\operatorname{Max}$ & 0.874 & -0.533 & 0.586 & 2.164 \\
\hline & Min & -1.263 & -2.802 & -3.594 & -2.073 \\
\hline & Mean & 0.2006 & -1.7242 & -0.5096 & 1.05455 \\
\hline
\end{tabular}

The relation between $\mathrm{Ca}^{2+}$ and $\mathrm{SO}_{4}{ }^{2-}$, presented positive relation $(\mathrm{r}=0.91$; Table 5 and Fig. $6 \mathrm{~d})$, indicating that gypsum is a source of $\mathrm{Ca}^{2+}$. The correlation between $\mathrm{SO}_{4}{ }^{2-}$ and $\mathrm{Mg}^{2+}(\mathrm{r}=0.47$; Table 5 and Fig. 6e) suggest that may also be derived by dissolution of gypsum to produce magnesium in the dedolomitization reaction. Therefore, the concentration of $\mathrm{HCO}_{3}{ }^{-}$in the water diminishes and decreases the $\mathrm{pH}$ (Fig. 6f), producing undersaturation of dolomite and oversaturation of the calcite, therefore contributing to an additional dissolution as well as the increase in the $\mathrm{Mg}^{2+}$ concentration in water.

Trace elements ( $\mathrm{Ba}, \mathrm{Cu}, \mathrm{Fe}, \mathrm{Li}$, and $\mathrm{Zn}$ ) and nitrate do not show a strong correlation neither between them or with the rest of the chemical variables examined. This behavior can be somehow attributed, partially, to man-made pollution. Elements like B and Sr presents strong correlation with $\mathrm{Cl}^{-}, \mathrm{Na}^{+}, \mathrm{Mg}^{2+} \mathrm{y} \mathrm{Ca}^{2+}$, one interpretation of these observations was that these trace elements in groundwater had similar hydrochemical characteristics in the study area.

The cluster analysis (Ward, 1963) was performed to identify the source between major ion concentration and trace elements for eighteen variables. Fig. 7 show the relationship between these variables. The variables $\mathrm{HCO}_{3}, \mathrm{Mg}, \mathrm{Na}, \mathrm{K}, \mathrm{Mn}$ and $\mathrm{Li}$ fall in the cluster 1 , whereas $\mathrm{SO}_{4}, \mathrm{Cl}, \mathrm{Ca}, \mathrm{F}, \mathrm{B}, \mathrm{Sr}$, Fe belong to cluster 2. Moreover, $\mathrm{NO}_{3}, \mathrm{Cu}, \mathrm{Ba}, \mathrm{Zn}$ fall in cluster 3 . The dendrogram suggests that the presence of major and minor ions are chiefly controlled by rock-water interaction and residence time of groundwater in the aquifer (Fig. 7). The ions of group 3 indicate impact of antropogenic contamination sources (discharge of urban and industrial wastewater).

\subsection{Ion speciation in groundwater}

The speciation of total ions in different forms is necessary for the understanding of hydrogeochemistry mechanisms; the model speciation showed that $\mathrm{HCO}_{3}{ }^{-}, \mathrm{Ca}^{2+}, \mathrm{Mg}^{2+}$ and $\mathrm{SO}_{4}{ }^{2-}$ are dominant species (Table 6 and Fig. 8).

The F, Ba, Li, Zn, and Fe were found as free or complex species (Table 6). For $\mathrm{Cu}$ element, the main species are present in the groundwater are $\mathrm{Cu}^{2+}$ and Copper hydroxide. $\mathrm{B}$ and $\mathrm{Si}$ are present in their acid form, these acids are not readily dissociate; they remain stable until $\mathrm{pH}>9$. The $\mathrm{Sr}$ is present as free element, like a bicarbonate ion and mineral as Celestite $\left(\mathrm{SrSO}_{4}\right)$. Mn is present as free element, like a bicarbonate ion and manganous carbonate (Manganese (II) Carbonate).

\subsection{Saturation index (SI)}

The saturation index is a measure of the departure from equilibrium of the water with respect to mineral phases. An SI value of zero, with an associated range of uncertainty ( \pm 0.1 ), indicates the water is in equilibrium with respect to the mineral phase; a value of less than zero indicates undersaturation (mineral dissolution is possible); and a value greater than zero indicates oversaturation (mineral precipitation is possible) (Sacks and Tihansky, 1996; Appelo and Postma, 2005). These calculations assume that the dissolved species in the groundwater are at chemical equilibrium.

Since primarily the bicarbonate, calcium, magnesium and sulphate compounds represent the increase in TDS, the analysis of mineral speciation was focused on calcite $\left(\mathrm{CaCO}_{3}\right)$, dolomite $\left(\mathrm{CaMgCO}_{3}\right.$, disordered 

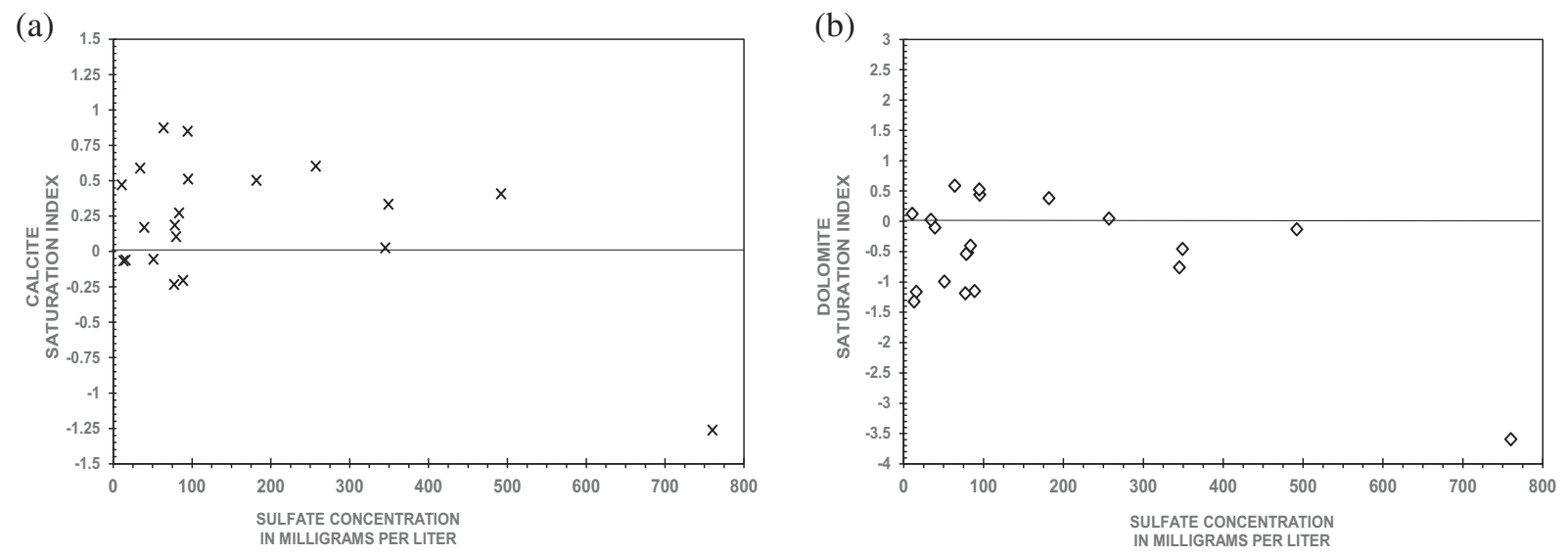

(c)

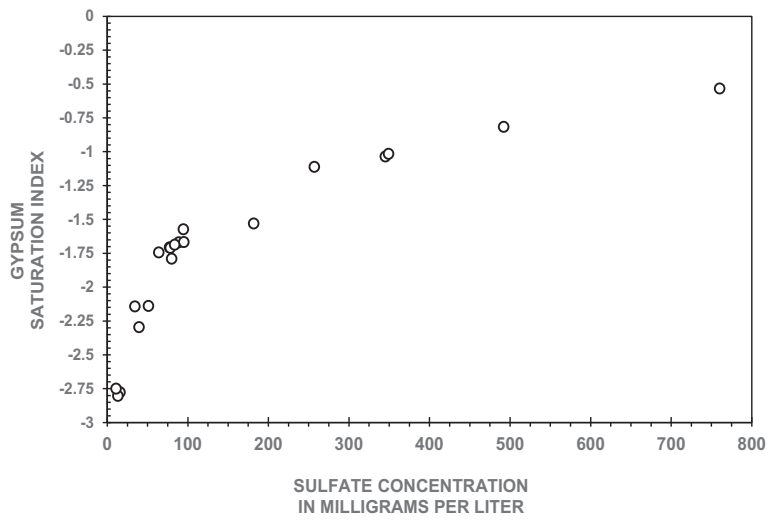

Fig. 9. Relation between a) calcite, b) disordered dolomite, and c) gypsum saturation index and sulphate concentration in water from wells sampled in November in 2014.

and crystalline) and gypsum $\left(\mathrm{CaSO}_{4}\right)$. The IS are summarized in Table 7. Most of the waters varied from equilibrium to oversaturated with respect to calcite. Water from one well (well 8) was undersaturated with calcite; this water had a high concentration of dissolved solids and sulphate.

The wells presented waters undersaturated and equilibrium with respect to "disordered" dolomite and saturated to oversaturated with respect to crystalline dolomite. Geochemical calculations have showed that solubility constant in the Puebla Valley aquifer is probably more similar to disordered dolomite than the crystalline $\left(\mathrm{K}_{\mathrm{T}}=16.6\right.$ to 16.7$)$, because magnesium concentrations increase along the flow paths. Most of the wells are in a state of undersaturated which means that even dolomite will dissolve in the water, that will be reflected through the increase magnesium concentration. All waters are undersaturated with respect to gypsum.

In addition, waters with lowest sulphate concentrations were oversaturated with respect to calcite and undersatured with respect to "disordered" dolomite (Fig. 9a, b). The Fig. 9c shows that the wells with lower sulphate concentrations were undersaturated with respect to the gypsum, but wells with the high sulphate concentrations were closest to equilibrium with gypsum (SI value of about -0.533 for well 8 ).

The hydrogeochemical process is summarized as follows: water initially in equilibrium with calcite dissolves gypsum and dolomite. The additional calcium and carbonate in the water causes calcite to become oversaturated and to precipitate. The combination of these three reactions is termed dedolomitization (Appelo and Postma, 2005; Sacks and Tihansky, 1996). Evidence of dedolomitization reactions and common ion effect is illustrated by concurrent increases in sulphates, calcium and magnesium concentrations in the upper aquifer by upwelling of mineralized water from deep aquifer (Salcedo-Sánchez et al., 2016).

The dedolomitization probably occurs in the deep aquifer and the middle unit. The removal of calcium from solution during calcite precipitation should affect the saturation state of groundwater with respect to gypsum; sulphate concentrations increase in deep wells like well 8 , which is dissolution and calcite precipitation also probably occur deep in the aquifer near the gypsum, and is evidenced by high concentrations of calcium and magnesium and could explain undersaturation with respect gypsum.

The maps of the spatial distribution of the saturation index with respect to calcite, dolomite and gypsum show the actual dissolution (Fig. 8). Calcite is distributed around oversaturation/equilibrium in almost all the wells (equilibrium is taken to be between $\mathrm{SI}=-0.1$ to 0.1 ). The calcite will tend to dissolve in the northeast and southwest of the city (Fig. 8a).

Dolomite is distributed around equilibrium to undersaturated (Fig. 8b), the undersaturated samples will tend to dissolve magnesium in the north and northwest of Puebla City.

The behavior of the saturation index with respect to gypsum explains the increased sulphate concentrations in wells that have not yet reached to equilibrium with this mineral and currently are undersaturated. As shown the Fig. 8c, the wells located outskirts of the city will tend to dissolve sulphates, caused by their undersaturated condition.

\section{Conclusions}

The urban zone of the Puebla Valley aquifer is associated to the main structures that control the distribution of the volcanic and sedimentary sequences. This implies a considerable reduction in the quality of water pumped from wells located in this area. In addition, the depth of the wells that are targeting the middle aquifer intensifies this problem since allows the hydraulic connection between shallow and middle aquifers (Fig. 10). 


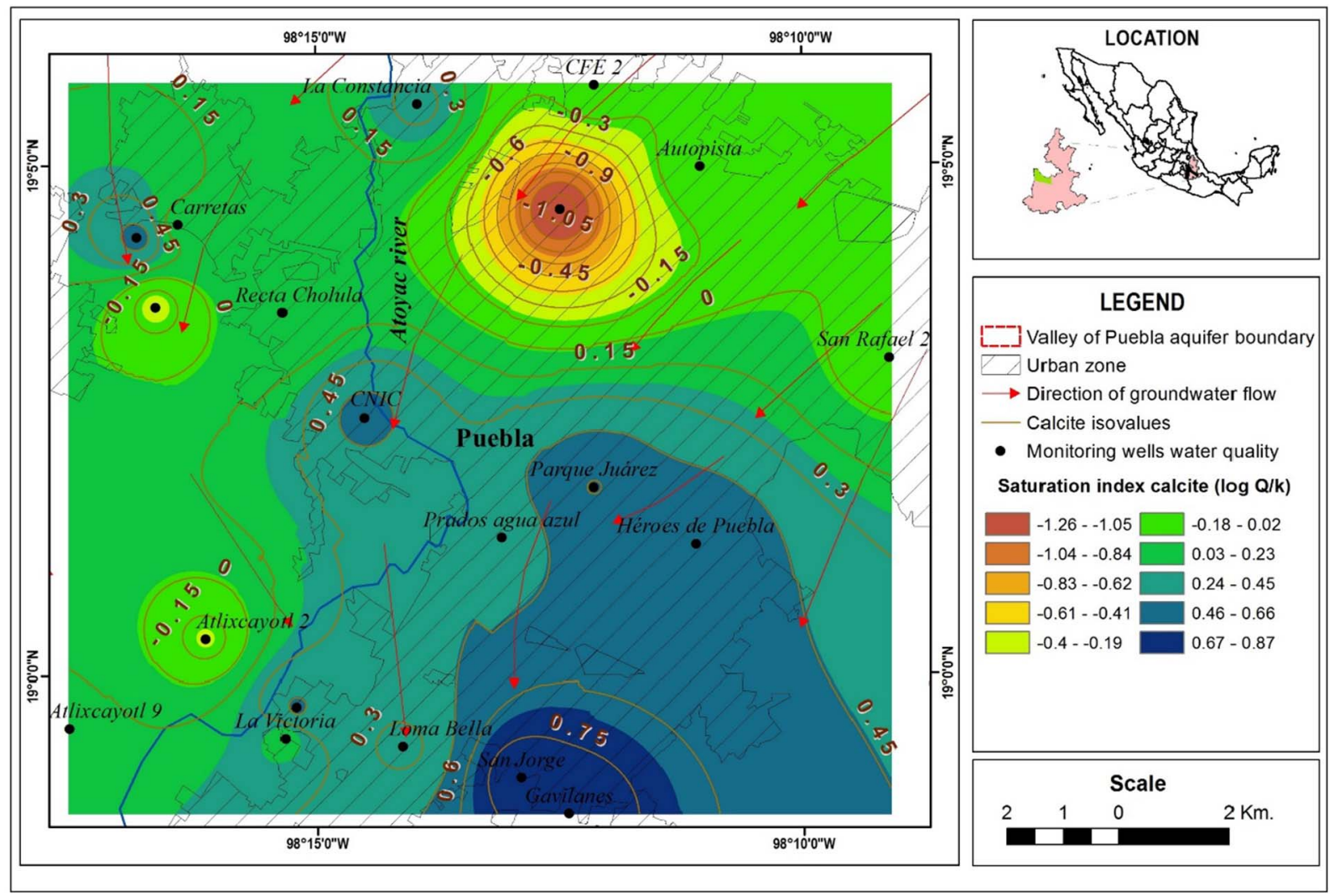

(a)

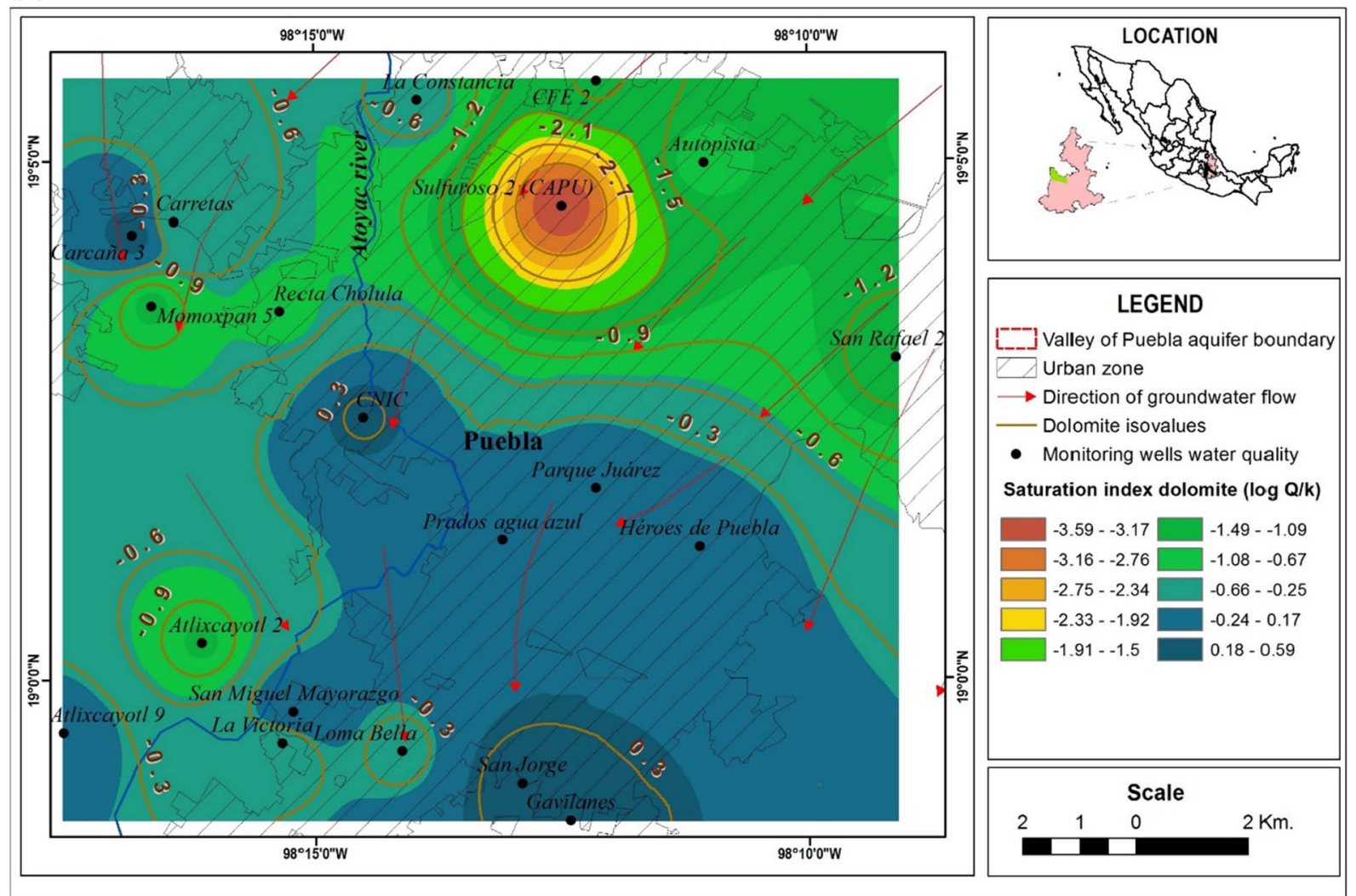

(b)

Fig. 10. Interpolation of saturation indices to determine the dissolution of calcite (a), dolomite (b) and gypsum (c). 


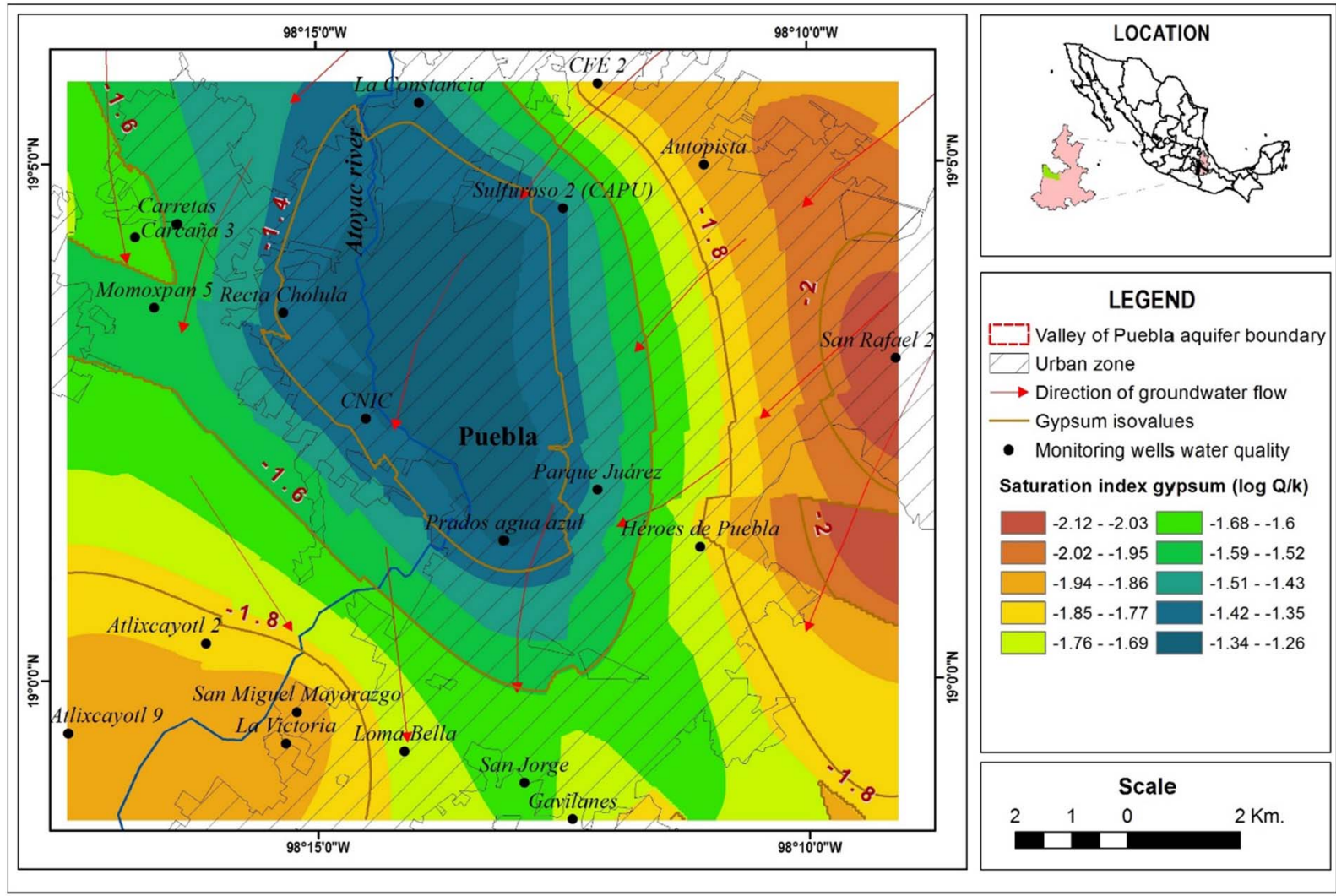

(c)

Fig. 10. (continued)

The hydrochemistry varies in relation to different water-rock interactions presence of calcite, dolomite, gypsum and volcanic rocks. This study has demonstrated that the chemical composition of groundwater differs according to water types.

The dominant facies containing $\mathrm{Ca}-\mathrm{HCO}_{3}, \mathrm{Mix}-\mathrm{HCO}_{3}$ and followed $\mathrm{HCO}_{3}-\mathrm{Ca}-\mathrm{SO}_{4}, \mathrm{SO}_{4}$-Ca. Puebla Valley deep aquifer follows the classic evolution of water in a carbonate aquifer. In the upgradient recharge area, groundwater composition is dominated by calcium and bicarbonate. In the discharge area, calcium, magnesium, and sulphate concentrations increase, which is consistent with gypsum and dolomite dissolution due upwelling of mineralized water, evidencing the dolomitization reactions in deep aquifers and facies evolution.

This analysis has revealed the content of ions in solution through the calculation of the saturation index, the results indicate that the water in the wells located on the outskirts of the city dissolve as much of sulphates to reach its equilibrium, wells with high concentrations of sulphates are coming to equilibrium in the solution with gypsum. While the area in which there is almost equilibrium with gypsum, greater dissolution of magnesium and calcium were presented due to the undersaturated condition with dolomite and calcite in this water. The computation of the saturation index of mineral phases with ions in solution $\left(\mathrm{Ca}^{2+}, \mathrm{Mg}^{2+}, \mathrm{SO}_{4}{ }^{2-}, \mathrm{HCO}_{3}{ }^{-}\right)$and their spatial interpolation allowed the identification of those wells that were in the process of mineralization (by increasing concentrations sulphates, calcium and magnesium) and areas where the process can occur.

Upwelling of mineralized water is probably accelerated by vertical flow through fractures and faults that connect deeper and shallower parts of the aquifer. Due to these conditions, urban wells should be drilled as far from these structures as possible in order to avoid contamination due to upwelling.

Most water quality parameters are below the limits of the Mexican standards acceptable for drinking water, and show a gradual deterioration in the water quality for WHO criteria. This article presents the preliminary results of heavy metals studied in the urban zone. Almost all the wells were found under Mexican standards due WHO criteria can be considered stricter than with Mexican norms; only Boron and Manganese had concentrations above the drinking water limits in moderate to large concentrations, which can cause health problems. The origin of these metals is from natural water-rock reaction processes in the aquifer, but B is an element that can be present in groundwater from weathering of rocks containing boron and wastewater from cleaning products and waste paint industries and varnishes, textiles, leather tanning, and electronics, among others.

The statistical results of cluster analysis indicate that the presence of major ions and physicochemical parameters are chiefly controlled by rock water interaction and residence time of groundwater and indicate the impact of anthropogenic contamination sources due the minor elements like $\mathrm{NO}_{3}, \mathrm{Cu}, \mathrm{Ba}, \mathrm{Zn}$.

\section{Acknowledgements}

This research was conducted under CONACYT scholarship awarded to Dr. Edith R. Salcedo.

\section{References}

APHA, AWWA, WEF, 2005. Standard Methods for the Examination Water and Wastewater, 21st ed. APHA, AWWA, WEF, Washington, D.C. EUA.

Appelo, C.A.J., Postma, D., 2005. Geochemistry, Groundwater and Pollution, 2nd ed. A.A. Balkema Publishers, Leiden, The Netherlands (683 pp.).

Aqueous Solutions LCC, 2016. Geochemist's Workbench (Version 11) [Software]. Department of Geology at the University of Illinois Urbana Champaign. https://www. gwb.com/.

Ayuntamiento de Puebla, 2014. Programa Municipal de Desarrollo de Puebla 2014-2018. Gobierno Municipal de Puebla, México.

Baldassare, G., Pagliarulo, P., Zuffianò, L.E., 2011. Water composition and minerals equilibria at the syri $\mathrm{i}$ kalter spring and in the bistrica river (south albania). Water Resour. 38 (5), 662-669. http://dx.doi.org/10.1134/S0097807811050022.

Carrillo-Rivera, J.J., Cardona, A., Huízar-Álvarez, R., Graniel, E., 2008. Response of the 
interaction between groundwater and other components of the environment in Mexico. Environ. Geol. 55 (2), 303-319.

Carucci, V., Petitta, Marco, Aravena, R., 2012. Interaction between shallow and deep aquifers in the Tivoli Plain (Central Italy) enhanced by groundwater extraction: a multi-isotope approach and geochemical modeling. Appl. Geochem. 27, 266-280.

CONAGUA, 2015. Actualización de la disponibilidad media anual de agua en el acuífero Valle de Puebla (2104), Estado de Puebla. Comisión Nacional del Agua, México. http://www.conagua.gob.mx/Conagua07/Aguasubterranea/pdf/DR_2104.pdf.

DOF, 2001. Norma Mexicana NMX-AA-072-SCFI-2001 Análisis de Agua - Determinación de Dureza Total en Aguas Naturales, Residuales y Residuales Tratadas. Secretaría de Comercio y Fomento Industrial. Diario Oficial de la Federación (DOF). (13 de agosto de 2001).

DOF, 2003. NOM-230-SSA1-2002, Salud ambiental. Agua para uso y consumo humano, requisitos sanitarios que se deben cumplir en los sistemas de abastecimiento públicos y privados durante el manejo del agua. Procedimientos sanitarios para el muestreo". Diario Oficial de la Federación (DOF). 4 de noviembre de 2003.

DOF, 2004. Modificación de la Norma Oficial Mexicana NOM-127-SSA1-2004 Salud ambiental Agua para uso y consumo humano Límites permisibles de calidad y tratamientos a que debe someterse el agua para su potabilización. Secretaria de Salud. Diario Oficial de la Federación (DOF). (20 de junio de 2000).

DOF, 2016. Acuerdo por el que se da a conocer el resultado de los Estudios técnicos de Aguas Nacionales subterráneas del acuífero Valle de Puebla, clave 2104, en el Estado de Puebla, Región Hidrológico-Administrativa Balsas. Comisión Nacional del Agua Diario Oficial de la Federación (DOF). (09 de febrero de 2016).

Dyer, S.D., Caprara, R.J., 2009. A method for evaluating consumer product ingredient contributions to surface and drinking water: boron as a test case. Environ. Toxicol. Chem. 16, 2070-2081.

Edmunds, W.M., Carrillo-Rivera, J.J., Cardona, A., 2002. Geochemical evolution of groundwater beneath Mexico City. J. Hydrol. 258, 1-24.

EPA, 2007. Drinking Water Standards and Health Advisories Table. United States Environmental Protection Agency. https://www3.epa.gov/region9/water/drinking/ files/dwsha 0607.pdf.

Esteller, M.V., Rodríguez, R., Cardona, A., Padilla, L., 2012. Evaluation of hydrochemical changes due to intensive aquifer exploitation: case studies from Mexico. Environ. Monit. Assess. 184 (9), 5725-5741.

Flores-Márquez, E.L., Jiménez-Juárez, G., Martínez-Serrano, R.G., Chávez, R.E., SilvaPérez, D., 2006. Study of geothermal water intrusion due to groundwater exploitation in the Puebla Valley aquifer system, Mexico. Hydrogeol. J. 14, 1216-1230.

Gárfias, J., Arroyo, N., Aravena, R., 2010. Hydrochemistry and origins of mineralized waters in the Puebla aquifer system, Mexico. Environ. Earth Sci. 59 (8), 1789-1805.

Guey-Shin, S., Bai-You, C., Chi-Ting, C., Pei-Hsuan, Y., Tsun-Kuo, C., 2011. Applying factor analysis combined with kriging and information entropy theory for mapping and evaluating the stability of groundwater quality variation in Taiwan. Int. J. Environ. Res. Public Health 8, 1084-1109.

Hem, J.D., 1992. Study and Interpretation of the Chemical Characteristics of Natural Water. US Geological Survey Water-supply Paper 2254. US Government Print Office, Washington DC.

INEGI, 2010. Censo de Población y vivienda 2010. Estado de Puebla. Instituto Nacional de Estadística y Geografía. http://www.censo2010.org.mx/.

Jalali, M., 2006. Chemical characteristics of groundwater in parts of mountainous region, Alvand, Hamadan, Iran. Environ. Geol. 51, 433.

Jalali, M., Jalali, M., 2016. Geochemistry and background concentration of major ions in spring waters in a high-mountain area of the Hamedan (Iran). J. Geochem. Explor. 165 (1), 49-61.

Martín del Campo, M.A., Esteller, M.V., Expósito, J.L., Hirata, R., 2014. Impacts of urbanization on groundwater hydrodynamics and hydrochemistry of the toluca valley aquifer (mexico). Environ. Monit. Assess. 186 (5), 2979-2999. http://dx.doi.org/10. 1007/s10661-013-3595-3.

Morán-Ramírez, J., Ledesma-Ruiz, R., Mahlknecht., Ramos-Leal J.A., 2016. Rock-water interactions and pollution processes in the volcanic aquifer system of Guadalajara, Mexico, using inverse geochemical modeling. Apply Geoche. 68, 79-94.

Morell, I., Pulido-Bosch, A., Daniele, L., Cruz, J.V., 2008. Chemical and isotopic assessment in volcanic thermal waters: cases of Ischia (Italy) and Sâo Migul (Azores, Portugal). Hydrol. Process. 22, 4386-4399.

Nandimandalam, J.R., 2012. Evaluation of hydrogeochemical processes in the Pleistocene aquifers of Middle Ganga Plain, Uttar Pradesh, India. Environ. Earth Sci. 65, 1291.

Parkhurst, D.L., Appelo, C.A.J., 1999. User' guide to PHREEQC a computer program for speciation, reaction-path, ID transport, and inverse geochemical calculations. US Geol. Surv. Water Resour. Inv. Rep. 99-4259, 312.

Sacks, L.A., Tihansky, A.B., 1996. Geochemical and isotopic composition of ground water, with emphasis on sources of sulfate, in the Upper Floridan Aquifer and Intermediate Aquifer System in southwest Florida. US Department of the Interior, US Geological Survey.

Sacks, L.A., Herman, J.S., Kauffman, S.J., 1995. Controls on high sulfate concentrations in the Upper Floridan aquifer in southwest Florida. Water Resour. Res. 31 (10), 2541-2551.

Salcedo-Sánchez, E.R., Esteller, M.V., Garrido Hoyos, S.E., Martínez-Morales, M., 2013. Groundwater optimization model for sustainable management of the Valley of Puebla aquifer, Mexico. Environ. Earth Sci. 70 (1), 337-351.

Salcedo-Sánchez, E.R., Garrido Hoyos, S.E., Esteller Alberich, M.V., Martínez Morales, M., 2016. Application of water quality index to evaluate groundwater quality (temporal and spatial variation) of an intensively exploited aquifer (Puebla Valley, Mexico). Environ. Monit. Assess. 188 (10), 1-20.

SMN, 2017. Información por entidad federativa de lluvia $(\mathrm{mm})$ total acumulada mensual 2014. http://smn.cna.gob.mx/tools/DATA/Climatolog\%C3\%ADa/Pron\%C3\% B3stico\%20clim\%C3\%A1tico/Temperatura\%20y\%20Lluvia/PREC/2014.pdf.

StatSoft, Inc, 2011. STATISTICA (data analysis software system), version 10. www. statsoft.com.

Ward, J.H., 1963. Hierarchical grouping to optimize an objective function. J. Am. Stat. Assoc. 58 (301), 236-244.

Waterloo Hydrogeologic, 1999. User's Guide of Aquachem (vs. 4) Waterloo, Ontario Canada. Waterloo Hydrogeologic, Inc.

WHO (World Health Organization), 2003a. Iron in drinking-water background document for development of WHO guidelines for drinking-water quality. In: World Health Organization, Geneva. 2003. http://www.who.int/water_sanitation_health/dwq/ chemicals/iron.pdf.

WHO (World Health Organization), 2003b. Barium in drinking-water background document for development of WHO guidelines for drinking-water quality. In: World Health Organization, Geneva. 2003. http://www.who.int/water_sanitation_health/ dwq/chemicals/barium.pdf.

WHO (World Health Organization), 2008. Guidelines for Drinking-Water Quality [Electronic Resource]: Incorporating 1st and 2nd Addenda, 3rd ed. vol. 1 (Geneva, Switzerland, Recommendations).

WHO (World Health Organization), 2010. Chemical Hazards in Drinking-water-boron. World Helth Organization. http://www.who.int/water_sanitation_health/dwq/ chemicals/boron/en/.

WHO (World Health Organization), 2011a. Guidelines for Drinking Water Quality, 4th edition. (Geneva, Switzerland).

WHO (World Health Organization), 2011b. Manganese in Drinking Water. Background Document for WHO Guidelines for Drinking Water Quality. WHO/SDE/WSH/03.04/ 104/Rev/1. 